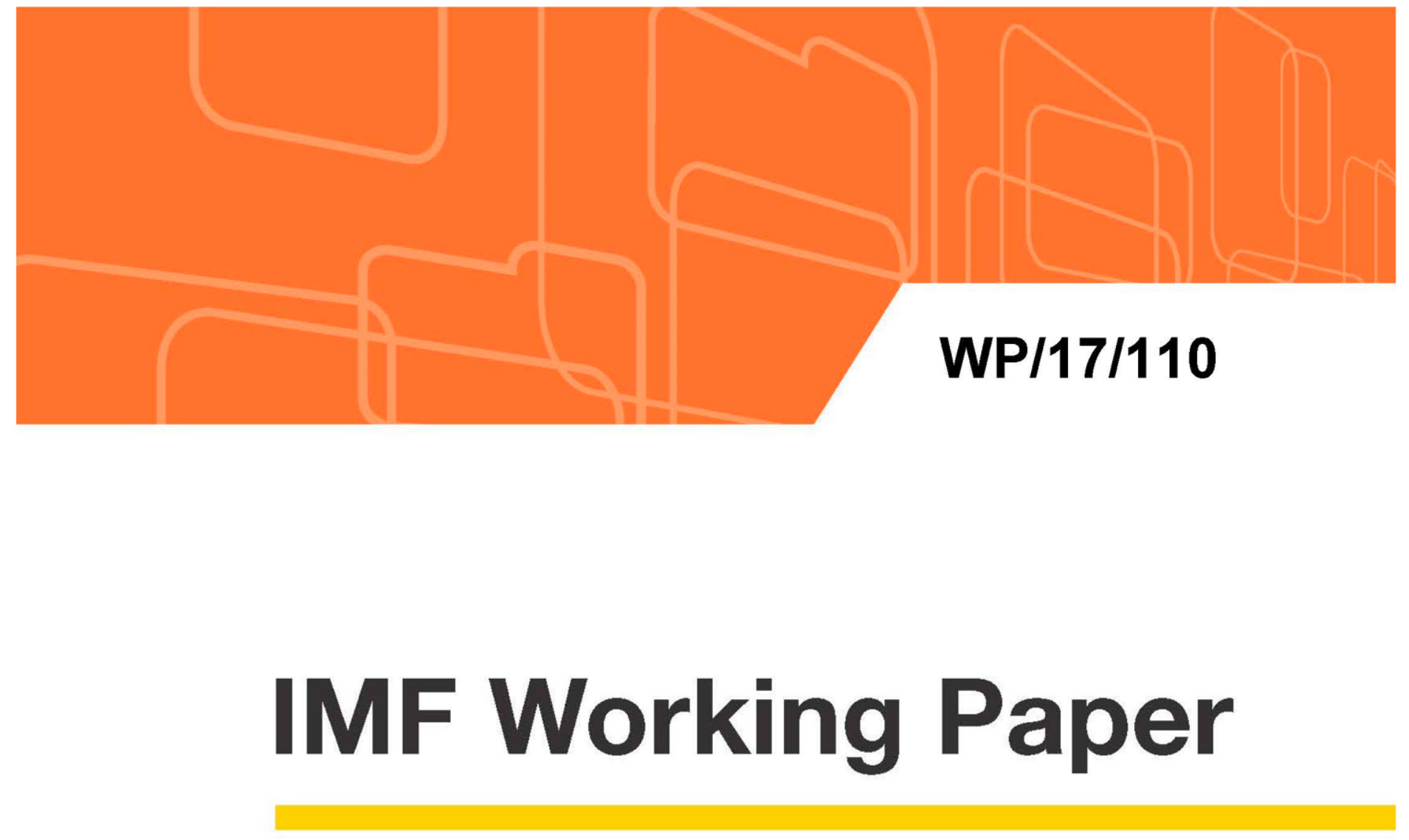

\title{
Can They Do It All? Fiscal Space in Low-Income Countries
}

by Anja Baum, Andrew Hodge, Aiko Mineshima, Marialuz Moreno Badia, and René Tapsoba 


\section{WP/17/110}

\section{IMF Working Paper}

\section{Can They Do It All? Fiscal Space in Low-Income Countries}

by Anja Baum, Andrew Hodge, Aiko Mineshima, Marialuz Moreno Badia, and René Tapsoba 


\title{
IMF Working Paper
}

Fiscal Affairs Department

\section{Can They Do It All? Fiscal Space in Low-Income Countries \\ Prepared by Anja Baum, Andrew Hodge, Aiko Mineshima, Marialuz Moreno Badia, and René Tapsoba ${ }^{1}$}

Authorized for distribution by Bernardin Akitoby and Catherine Pattillo

May 2017

IMF Working Papers describe research in progress by the author(s) and are published to elicit comments and to encourage debate. The views expressed in IMF Working Papers are those of the author(s) and do not necessarily represent the views of the IMF, its Executive Board, or IMF management

\begin{abstract}
According to U.N. estimates, low-income countries will have to increase their annual public spending by up to 30 percent of GDP to achieve the Sustainable Development Goals (SDGs), raising the question of whether they can do it all. This paper develops a new metric of fiscal space in low-income countries that accounts for macroeconomic uncertainty, allowing us to assess whether those spending needs can be accommodated. Illustrative simulations based on this methodology imply that, even under benign conditions, the fiscal space available in lowincome countries is likely insufficient to undertake the spending needed to achieve the SDGs. Improving public investment efficiency and domestic revenue mobilization can somewhat narrow the gap but it will require major efforts relative to recent trends.
\end{abstract}

JEL Classification Numbers: E62, H62, H63

Keywords: fiscal space, public debt, sustainability, SDGs, low-income countries

Author's E-Mail Address: ABaum@imf.org, AHodge@,imf.org, AMineshima@imf.org, MMorenobadia@,imf.org, RTapsoba@imf.org

\footnotetext{
${ }^{1}$ We are grateful to Bernardin Akitoby, Sanjeev Gupta, Catherine Pattillo, Abdel Senhadji, IMF colleagues, and participants in the IMF-JICA Conference on "Regional Developments: Fiscal Risks, Fiscal Space, and the Sustainable Development Goals" (February 2, 2017) for helpful comments. All errors remain ours. Juan Farah Yacoub and Young Kim provided excellent research assistance while Nadia Malikyar provided excellent editorial and administrative support.
} 
I. Introduction

\section{Contents}

II. Stylized Facts

III. Methodology

IV. Fiscal Behavior $\underline{15}$

V. Results 17

Baseline and Macroeconomic Uncertainty

Fiscal Behavior

Financing Mix and the Real Exchange Rate

Policy Scenarios

VI. Conclusions

References

Boxes

1. Materialization of Contingent Liabilities in LICs: Some Examples

Figures

1. Incremental Estimated Annual Investment Needs

2. LICs: Decomposition of Government Debt Evolution

3. Interest Growth Differentials

4. LICs: Change in Real Exchange Rate

5. LICs: Financing Mix of Sample Countries

6. LICs: Real Interest Rate Differentials

7. Volatilities of Macroeconomic Variables

8. Largest Annual Changes on Tax Revenue

9. LIC: Real GDP Growth $\frac{10}{18}$ 
Tables

1. Estimation Results for Fiscal Reaction Function

A4.1. Estimation Result for the Fiscal Reaction Function: Further Specifications

34

Appendices

I. Data $\underline{26}$

II. Stock Flow Adjustments and Contingent Liabilities

$\underline{27}$

III. The Stochastic Simulation Model

$\underline{28}$

IV. Fiscal Reaction Function: Econometric Issues and Robustness

31




\section{INTRODUCTION}

The Sustainable Development Goals (SDGs) launched in September 2015 establish ambitious objectives to end poverty, protect the planet, and ensure prosperity for all by 2030 (United Nations 2015). The new development agenda is broader in scope than the nowexpired Millennium Development Goals (MDGs) not only because the SDGs are universal but also because the number of goals and targets have been expanded. ${ }^{2}$ From inception, it was clear this ambition would have to be accompanied by significant efforts to boost the financing resources available to developing countries (IMF 2015a, 2015b, and 2016a). Although there is significant uncertainty regarding the additional spending needs, the numbers are likely to be very large. For example, Schmidt-Traub (2015) estimated that the average annual investment increase required in low-income countries (LICs) to attain these goals could reach up to $\$ 400$ billion (or 50 percent of their GDP). Although a large share could potentially be

Figure 1. Incremental Estimated Annual Investment Needs, Average for 2015-301 (Billions, in 2013 USD)

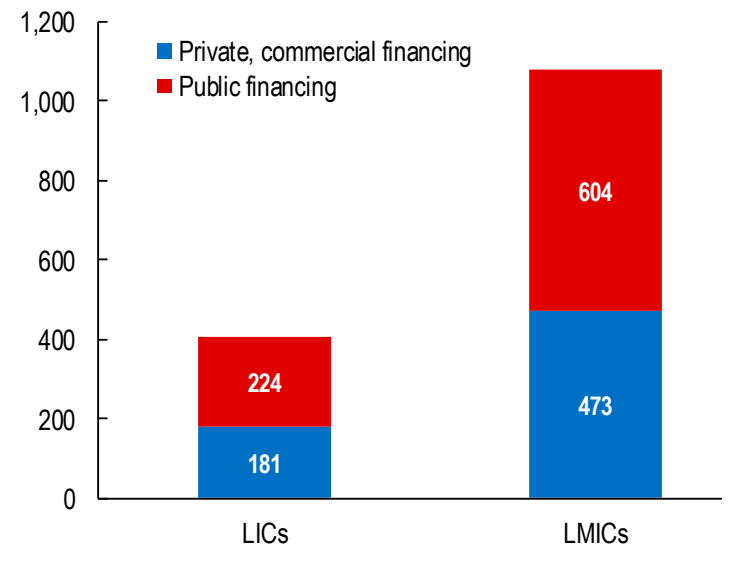

Sources: U.N., Sustainable Development Solutions Network.

${ }^{1}$ Estimates include spending needs related to climate mitigation and adaptation. For details see Schmidt-Traub (2015). privately financed (Figure 1), the heavy burden imposed on the public sector cannot be overstated even accounting for aid. Moreover, in a world where too low growth for too long is a real risk, there is an increasing concern that LICs may no longer benefit from the macroeconomic tailwinds they enjoyed at the time of the launch of the MDGs. The question is then whether LICs can do it all.

Answering this question requires assessing the fiscal space in LICs from a dynamic perspective, i.e., considering not only where they stand today but also where they could be in the future. The literature, however, does not provide a clear framework to address that question:

- $\quad$ Recent papers have introduced a multidimensional concept of fiscal space building on the seminal work of Heller (2005), but the focus is squarely on advanced and emerging market economies (IMF 2016b; Botev, Fournier and Mourougane 2016). In that context, fiscal space captures the ability of a government to raise spending or lower taxes without endangering market access or debt sustainability. A fundamental constraint to apply these frameworks to LICs is that they take as given the access to financing and the existence of well-functioning institutions.

\footnotetext{
2 The MDGs have 8 goals and 18 targets focusing on ending extreme poverty. By contrast, the SDGs include 17 goals and 169 targets focusing on sustainable development-which comprises not only economic development but also social inclusion and environmental sustainability - and calling for universal access to basic services and infrastructure.
} 
- $\quad$ Other studies focus on LICs but they mainly look at the government's ability to secure additional budgetary resources (Brun and others 2006; Heller and others 2006; Briguglio and others 2008; Roy and Heuty 2009; Schick 2009; Horton and ElGanainy, 2012; and World Bank 2013 and 2015). That ability comes not only from accessing additional borrowing but also from greater predictability of grants, revenue mobilization, and reorienting expenditure or increasing its efficiency. In the same vein, Aizienman and Jinjarak (2010) measure fiscal space as the inverse of tax-years (actual tax collection, averaged across several years to smooth for business cycle fluctuations) that are needed to repay the outstanding public debt. Some papers capture these multifaceted aspects through composite indices (IMF 2013a; Roy, Heuty, and Letouzé 2007; World Bank 2009; and UNDP 2011). A nascent strand of the literature also looks at the interrelationship between a country's revenue raising capacity and public investment. The underlying idea is that improving physical and human capital may foster growth and enable higher revenue collection, thereby expanding the available fiscal space..$^{3}$ A shortcoming of this literature, however, is that it does not fully account for macroeconomic uncertainty.

- $\quad$ A few papers take a probabilistic approach to debt sustainability and define fiscal space as the difference between the current public debt level and the debt limit implied by the country's historical record of fiscal adjustment (Ostry and others 2010; and Ghosh and others 2013). This framework explicitly accounts for uncertainty and defines the debt limit as a point beyond which fiscal solvency fails. Arguably, being close to that limit is an unstable position that LICs would likely try to avoid at all costs. To address that concern, Adedeji and others (2016) consider instead a desirable debt margin for a given debt limit. ${ }^{4}$ However, they do not control for some important characteristics of LICs such as the financing mix, fiscal risks, and the endogenous response of fiscal policy to macroeconomic shocks.

The purpose of this paper is to develop a new metric of fiscal space in LICs that addresses some of the shortcomings in the existing literature. The approach is similar in spirit to that developed in Celasun, Debrun and Ostry (2007) and Debrun, Jarmuzek, and Shabunina (2017) but tailoring it to the LIC context. In particular, it defines a safe debt level based on three criteria: (1) the government should remain solvent (i.e., it should be able to pay its debt) with a high probability; (2) macroeconomic and fiscal shocks and their correlation should be accounted for; and (3) in the face of shocks, returning to safe debt levels should imply a feasible policy path. Fiscal space is then calculated as the distance between the current and safe debt levels. One of the main contributions of this paper is to develop a framework that

\footnotetext{
${ }^{3}$ This literature has given rise to a modified version of the permanent income hypothesis (MPIH), on the ground that the traditional permanent income hypothesis - which advocates the consumption of a constant flow of natural resources revenue - is questionable in the context of LICs given their large infrastructure gaps and limited access to international markets (van der Ploeg and Venables 2011; Berg and others 2013; Buffie and others 2012; IMF 2012; Deléchat and others 2017).

${ }^{4}$ The debt limit is taken from the Debt Sustainability Framework for Low-Income Countries (IMF and World Bank 2012). As an alternative, they also use self-imposed debt rules for a few countries.
} 
accounts for the endogenous nature of fiscal policy as well as some distinctive characteristics of LICs such as: (1) the evolving financing mix; (2) financing constraints; and (3) exposure to terms of trade and exchange rate shocks. It also provides the flexibility to analyze policy scenarios that may potentially increase fiscal space such as revenue mobilization or the scaling-up of public investment. An additional contribution is that the stochastic framework typically applied to advanced and emerging market economies has been adapted to the dataconstrained environment of LICs while also allowing for the materialization of tail risks.

Illustrative simulations based on this methodology imply that, under benign conditions, the fiscal space available in LICs may be in the double digits but, not surprisingly, it will be insufficient to undertake the spending needed to achieve the SDGs. The results are starker when uncertainty about commodity prices and exchange rates is factored in. Also, changes to the financing mix away from concessional borrowing can severely limit the available space, particularly if the real exchange rate appreciation observed in many LICs over recent years was to reverse or financial conditions were to tighten. Improving public investment efficiency and domestic revenue mobilization can, however, contribute to narrowing the gap between the spending needs and the available fiscal space, but it will require major efforts relative to the trends of the recent past.

The rest of the paper is structured as follows. Section II presents some of the unique characteristics of LICs that justify our methodological approach. Section III sets out the methodology of the paper. Section IV discusses the fiscal behavior in LICs while section V presents the results. Section VI concludes with some policy implications.

\section{STYlized F ActS}

LICs have some features that differentiate them from advanced and emerging market economies. On the one hand, many of them have relatively low public debt levels (IMF 2015c), which would suggest they enjoy ample fiscal space to undertake much needed public investment. On the other, the efficiency with which LICs convert public investment into public capital is generally lower than in advanced and emerging market economies (Gupta and others 2014), thereby reducing the growth dividend and potential fiscal space. At the same time, LICs are subject to larger macroeconomic volatility and fiscal risks, creating the need for fiscal buffers to accommodate such shocks. In this section, we highlight some of the specific features that should be taken into account when assessing fiscal space. 


\section{Stylized fact 1: low public debt but increasing fiscal deficits}

Following the early wave of debt relief, ${ }^{5}$ public debt ratios declined significantly among LICs, reaching 23 percent of GDP by 2008 (Figure 2) ${ }^{6}$ The reduction in debt levels was partly explained by favorable macroeconomic conditions as reflected in the largely negative interest-growth differentials (Figure 3). Also, the real appreciation of the exchange rate during the last decade contributed to the positive debt dynamics. The median appreciation vis-a-vis the U.S. dollar was 2 percent- $3 \frac{1}{3}$ percent for mineral exporters and $12 / 3$ percent for nonmineral exporters (Figure 4). Terms-of- trade gains and, in some cases, large capital inflows were behind this appreciation.

These favorable trends started to reverse in 2009 and public debt began edging up as a result. The main factor has been the widening of fiscal deficits, initially explained by the scaling up of public investment and counter-cyclical policies undertaken in the aftermath of the global financial crisis (IMF 2014). More recently, lower commodity prices and a less-supportive global environment have led to a deceleration in economic activity - notably in sub-Saharan Africa (IMF 2016d) - pushing deficits further up, particularly among oil exporters.

\section{Stylized fact 2: decreasing reliance on concessional financing}

The LIC financing landscape has changed gradually since 2007 . Lower debt to multilateral and Paris Club creditors has been offset by increased borrowing from domestic

\footnotetext{
${ }^{5}$ The Heavily Indebted Poor Countries (HIPCs) initiative was launched in 1996 as the coordinated debt relief effort of multilateral, bilateral, and commercial creditors. It was later enhanced by the Multilateral Debt Relief Initiative (MDRI). The total cost of debt relief to creditors under the HIPC Initiative and MDRI is estimated at US\$74.8 billion, and US\$41.6 billion in end-2014 present value terms respectively (IMF 2016c).

${ }^{6}$ Throughout the rest of the paper, fragile and small states have been excluded from the LIC sample reflecting data constraints. Also, there is an argument to exclude these countries given their higher macroeconomic volatility related to civil conflicts and natural disasters. For more details, see Appendix I.
} 
markets, international capital markets, and nonParis Club bilateral creditors. As a result, the share of concessional loans to total debt declined from around 65 percent in 2001 to 40 percent by 2014 (Figure 5). Domestic financing has increased particularly in frontier $\mathrm{LICs}^{7}$, in some cases with an increased participation of nonresident investors. At the same time, several LICs gained access to international capital markets thanks to favorable growth and easy global liquidity conditions. The issuance of Eurobonds has reached US $\$ 41$ billion cumulatively since 2007 , with the majority issued during 2010-14 (IMF 2015c). In parallel, there has also been a marked increase in official bilateral lending from non-Paris Club creditors such as China, India, and Brazil.

The shift towards non-concessional external and domestic financing could undoubtedly worsen debt dynamics going forward. Real interest rates on non-concessional loans are on average 230bps above those of concessional loans (Figure 6). Within non-concessional financing, domestic loans have generally higher and more volatile real interest rates.
Figure 6. LICs: Real Interest Rate Differentials ${ }^{1}$ (Percent)

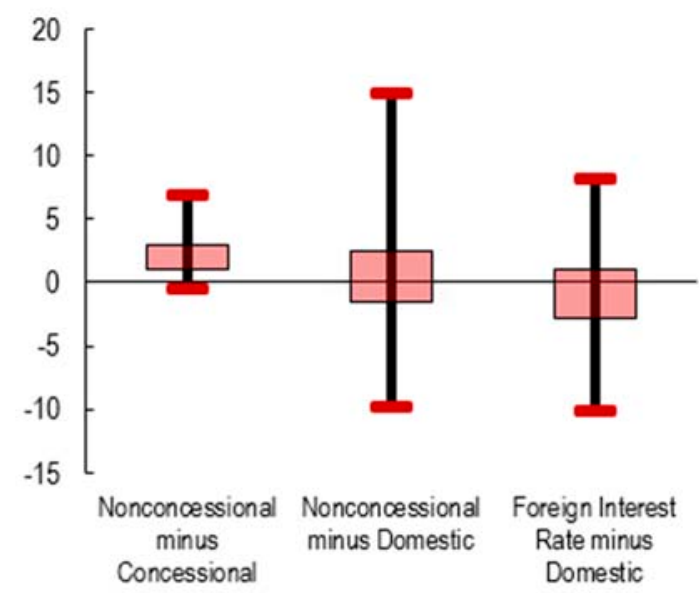

Sources: IMF, World Economic Outlook and Debt Sustainability Analysis Database.

${ }^{1}$ The sample comprises 28 LICs. For more details, see Appendix I. IMF, World Economic Outlook

${ }^{1}$ The sample comprises 28 LICs. For more details, see Appendix I.

\footnotetext{
${ }^{7}$ Frontier LICs are those countries that are closest to resembling emerging market economies in the depth and openness of financing markets and access to international sovereign bond markets. For the list of frontier markets included in our sample, see Appendix I.
} 
Nevertheless, exchange rate volatility can in some instances make the cost of external loans comparable or even higher.

\section{Stylized fact 3: high macroeconomic volatility and relatively low financial depth}

Over the last decade, macroeconomic volatility has been high in LICs, but not along all dimensions. In fact, growth in LICs was relatively strong and its standard deviation was lower than in advanced and emerging market economies (Figure 7). In contrast, terms of trade have been particularly volatile, followed by the real exchange rate. On the fiscal front, revenues have also fluctuated sharply, partly on account of grant inflows but also because of the large swings in commodity prices and related revenues (Figure 8). Limited capacity in policy management makes it difficult to reduce such volatilities, underlining the importance of maintaining adequate policy buffers.

\section{Figure 7. Volatilities of Macroeconomic Variables ${ }^{1}$}

(Standard deviations for 2005-15, sample median)

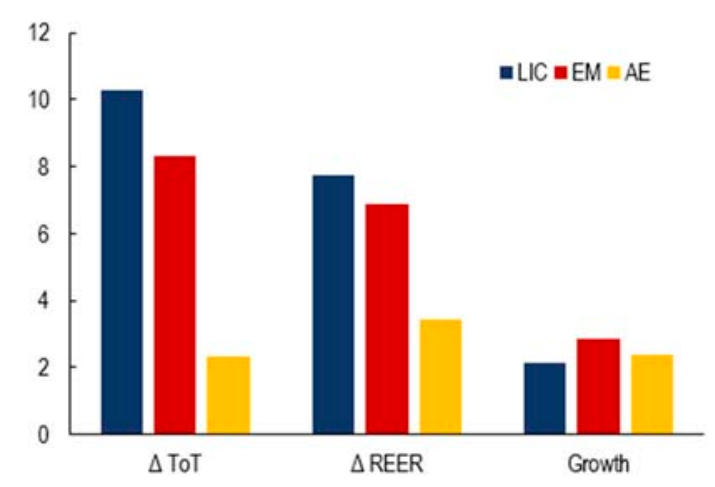

Sources: International Financial Statistics; and IMF, World Economic Outlook.

${ }^{1} \mathrm{AE}$ : advanced economies, EM: emerging market economies, LIC: low-income countries. The sample for LICs comprises 28 countries. For more details, see Appendix I.
Figure 8. Largest Annual Changes on Tax Revenue $^{1}$

(Percentage change, sample median)

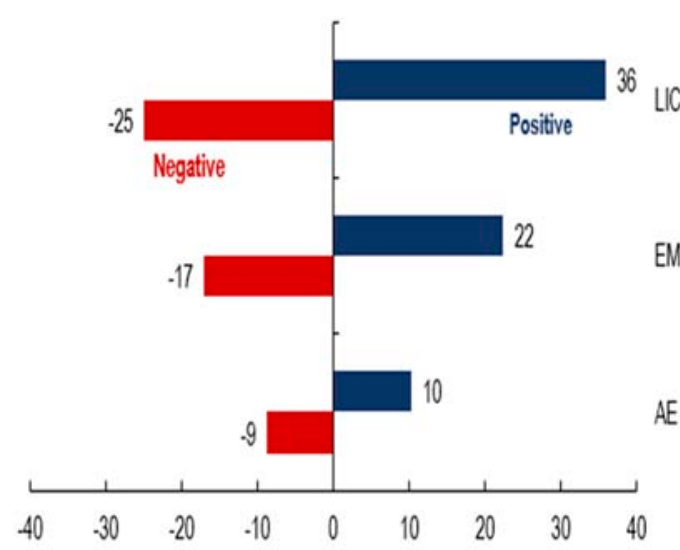

Sources: IMF, World Economic Outlook and Debt Sustainability Analysis Database.

${ }^{1} \mathrm{AE}$ : advanced economies, $\mathrm{EM}$ : emerging market economies, LIC: low-income countries. The sample for LICs comprises 28 countries. For more details, see Appendix I.

Looking ahead, growth prospects are clouded in many LICs given the still uncertain global environment. Notwithstanding recent improvements in commodity prices, the outlook is particularly somber among mineral exporters (Figure 9), many of which face liquidity stress and large imbalances and are struggling to adjust to falling revenues (IMF 2016e). Moreover, the scope for raising funds is still limited for many countries given under-developed domestic financial markets (Figure 10) and lack of market access. In addition, external financing conditions, although still relatively accommodative, are expected to tighten against the background of U.S. monetary policy normalization and a strong U.S. dollar. 
Figure 9. LIC: Real GDP Growth ${ }^{1}$ (Percent of GDP)

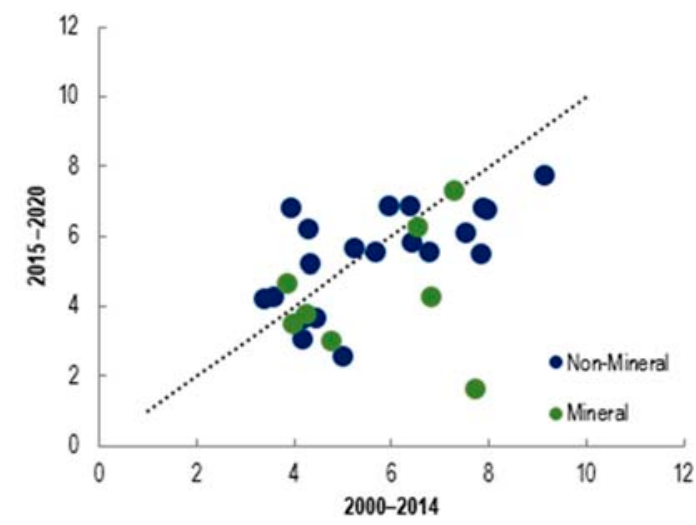

Source: IMF, World Economic Outlook.

${ }^{1}$ The sample comprises $28 \mathrm{LICs}$. For more details, see Appendix I.
Figure 10. Financial Depth, $2015^{1}$ (Ratio of M2 to GDP, percent)

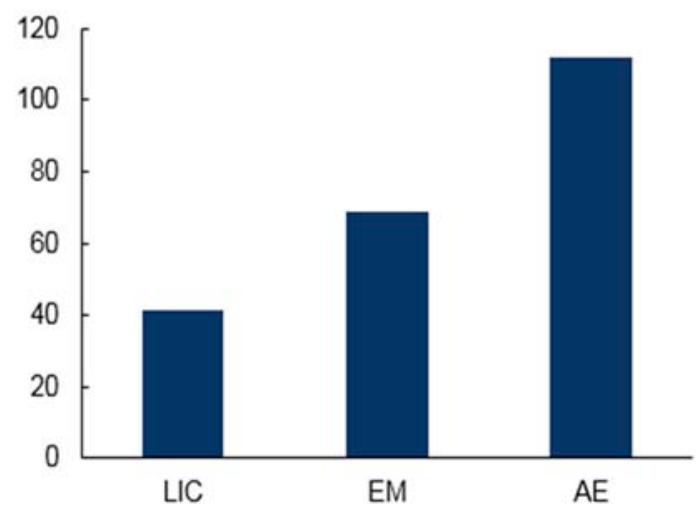

Source: IMF, World Economic Outlook.

${ }^{1} \mathrm{AE}$ : advanced economies, EM: emerging market economies, LIC: low-income countries. The sample for LICs comprises 28 countries. For more details, see Appendix I.

\section{Stylized fact 4: contingent liabilities as a source of fiscal risks}

Contingent liabilities are becoming a major source of fiscal risks in LICs. They can arise from various sources, based either on formal contractual obligations (explicit contingent liabilities), or on political pressures to take on the fiscal burden associated with defaults or arrears from SOEs, banking crises, sub-national entities and strategic private enterprises, as well as natural disaster recovery (implicit contingent liabilities) (Figure 11). Despite their growing importance, data on contingent liabilities is scarce and only a few LICs report them in their budget documents, leaving them exposed to substantial unforeseen fiscal costs when contingent liabilities materialize (IMF 2016f). ${ }^{8}$ An estimate based on available information for our sample of LICs shows that contingent liabilities have ranged between 0.7 and 14 percent of GDP in the recent past with the highest costs stemming from banking crises (Box 1 and Figure 12).

\footnotetext{
${ }^{8}$ According to the 2015 Open Budget Survey, only six out of the 28 countries in our sample (Bangladesh, Nigeria, Papua New Guinea, Senegal, Uganda and Zambia) disclose some (non-exhaustive) information on contingent liabilities (http://survey.internationalbudget.org/\#profile). The Macroeconomic and Financial Management Institute of Eastern and Southern Africa (MEFMI) recently initiated a set of studies aiming at quantifying and monitoring contingent liabilities in Southern and Eastern Africa. Although very encouraging, the data collected remain limited, not homogenous and comprehensive, which prevents any thorough crosscountry study.
} 
Figure 11. Main Sources of Contingent Liabilities in Low-income Countries

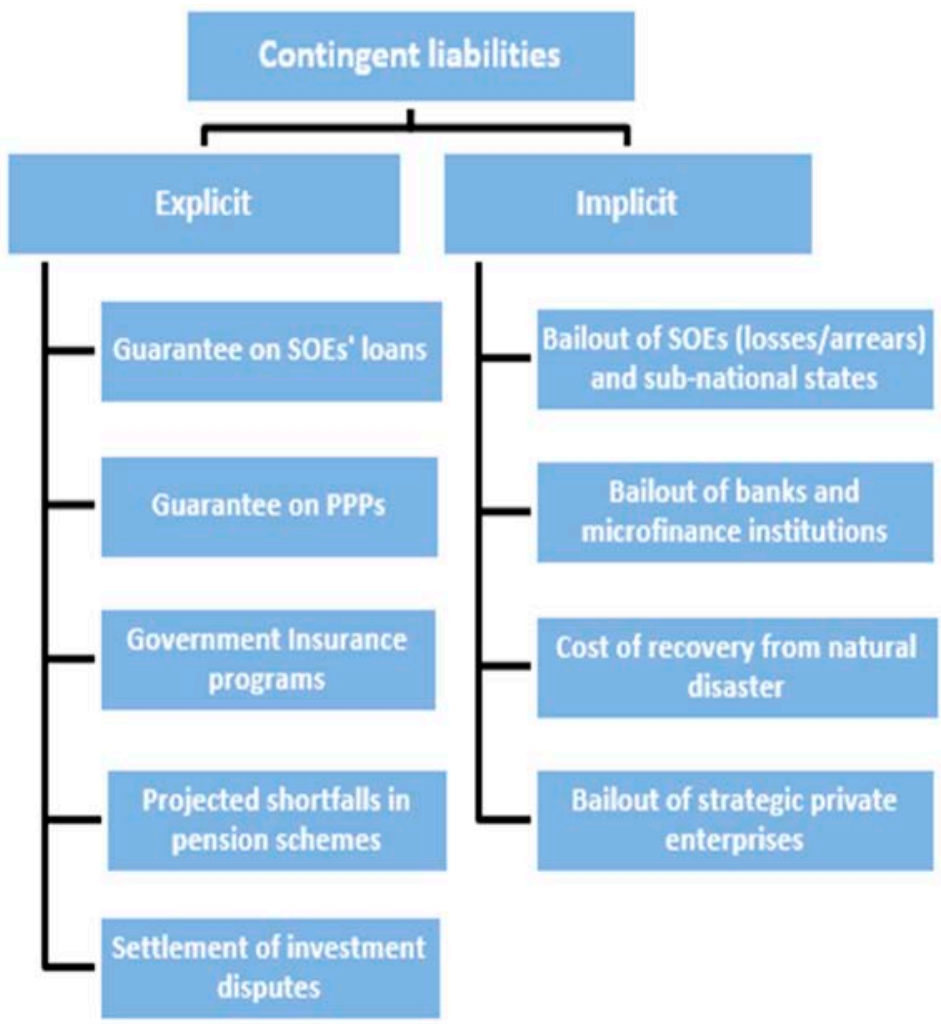

Figure 12. Materialization of Contingent Liabilities: Some Examples (Percent of GDP)

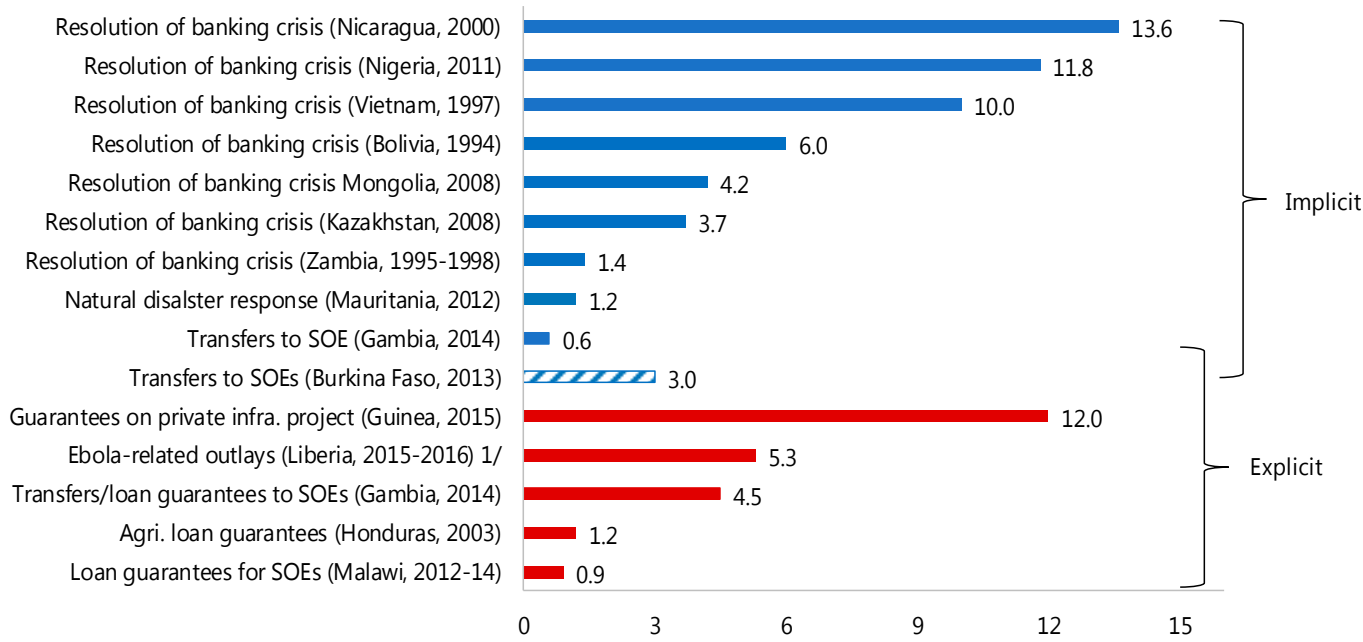

1/ 3.2 percent of GDP for 2015 and 2.1 percent of GDP for 2016. The amount covers only the cost that the government acknowledges.

Source: IMF staff reports, MEFMI (2013); and Laeven and Valencia (2012). 


\section{Box 1. Materialization of Contingent Liabilities in LICs: Some Examples}

\section{Called loan guarantees}

Guinea. At the request of the Ministry of Finance, the Central Bank issued guarantees during 2014 and 2015 to local and foreign banks to implement large-scale infrastructure projects (equivalent to 15.2 percent of GDP, 85 percent of which benefited from the guarantees). Starting in 2015, the guarantees were called and the Central Bank began settling the associated obligations.

\section{Transfers to state-owned enterprises (SOEs)}

The Gambia. Three SOEs (water and electricity, telecom, and groundnuts) encountered financial difficulties in 2014 due to: (i) general inefficiencies and mounting fuel costs; (ii) a sharp increase in domestic interest rates; and (iii) rejection of exports as a result of low quality. The SOEs called on loan guarantees that amounted to 4.5 percent of GDP (direct transfers added another 0.6 percent of GDP).

Burkina Faso. The two largest SOEs (SONABHY and SONABEL) hold monopoly power on the distribution of hydrocarbon products and electricity. In 2013, when the oil price peaked, these two companies received net government transfers equivalent to 3 percent of GDP. The transfers (implicit and explicit subsidies) covered losses brought about by the gap between domestic retail oil prices and international oil prices, as well as by fixed electricity tariffs.

\section{Banking crisis resolution}

Nigeria. During 2009-11, a severe banking crisis - involving more than 40 percent of the banking sector assets - took place. The government and the central bank took steps to mitigate the adverse effects of the crisis, which, by 2011, substantially raised public debt by as much as 11.8 percent of GDP (Laeven and Valencia 2012; IMF 2013b).

\section{Other}

Mauritania. In response to the 2011-12 drought and rising food prices, the authorities expanded an existing scheme of subsidized food shops, originally hoping to split the cost with donors. Ultimately, the authorities covered a larger than anticipated cost (1.2 percent of non-oil GDP in 2012) due to delayed donor disbursements and a more severe-than-expected drought impact.

Cote d'Ivoire. Insufficient traffic on a bridge relative to assumptions in a PPP contract triggered an implicit guarantee of 0.07 percent of GDP in 2015. While this materialized amount is small, Cote d'Ivoire's 2015 PPP portfolio included 114 projects for a total amount of about 75 percent of GDP, mostly in the transportation, energy, animal and fishing, and tourism sectors, which could potentially give rise to further fiscal risks.

\section{Methodology}

The approach in this paper is similar to that of Debrun, Jarmuzek, and Shabunina (2017). The framework relies on the distinction between the so-called debt limit and safe debt. The former is characterized as the level above which debt becomes unsustainable, abstracting from liquidity risks. That is, the point beyond which debt would rise indefinitely because the primary surplus would never be enough (in the absence of unrealistic adjustments) to offset the growing 
debt service (Ostry and others 2010). Safe debt is then defined as the level that would accommodate an increase in debt (resulting from a shock) without breaching the debt limit. The difference between the safe and current debt levels determines the fiscal space. Thus, in our proposed metric three ingredients are important:

- Identifying the debt limit or ceiling. In practice, this is difficult when the growthadjusted interest rate is persistently negative as it is the case in many LICs. In this paper, we take a pragmatic approach and use the public debt thresholds defined in the IMF/World Bank Debt Sustainability Framework (DSF) for LICs as proxies for debt limits. ${ }^{9}$ These thresholds capture the risk of debt distress while accounting for differences in institutional capacity as measured by the World Bank's Country Policy and Institutional Assessment (CPIA) index.

- Understanding the drivers of debt dynamics. This requires examining macroeconomic uncertainty and fiscal risks. As discussed in the previous section, distinctive features of LICs that influence recent debt dynamics and should be controlled for (apart from the standard interest-growth differential) include: the volatility of terms of trade and real exchange rates; the changing financing mix; financing constraints; and contingent liabilities.

- $\quad$ Controlling for the endogenous response of fiscal policy. The government's ability to sustain primary balances at or above their debt-stabilizing levels will ultimately determine whether they can keep debt levels below the limit. Importantly, fiscal behavior needs to account for the differences between mineral and non-mineral producers and their response to shocks.

Our framework is guided by the standard debt equation based on the evolution of the existing stock of debt, the contemporaneous fiscal behavior, and other components (here used as a proxy for contingent liabilities) as follows:

$$
\begin{aligned}
& d_{i t}=\frac{1}{1+g_{i t}}\left[d_{i(t-1)}+\left(\alpha_{i}^{d} r_{i t}^{d}+\alpha_{i}^{f} r_{i t}^{f}\right) \mathrm{d}_{i(t-1)}+\Delta \varepsilon_{i t}\left(1+r_{i t}^{f}\right) \alpha_{i}^{f} d_{i(t-1)}\right]-p b_{i t}+S F A_{i} \\
& r_{i t}^{f}=\beta_{i}^{C} r_{i t}^{C}+\beta_{i}^{N C} r_{i t}^{N C}
\end{aligned}
$$

\footnotetext{
9 The Debt Sustainability Framework (DSF) was last reviewed in 2012 and work on the next review is ongoing, so these thresholds are subject to change. An alternative would be to use the self-imposed public debt limits that some LICs have adopted to contain fiscal risks (IMF 2009; Budina and others 2012). Among LICs, two currency unions (WAEMU and CEMAC) have a convergence criteria of public debt not exceeding 70 percent of GDP. Four other LICs have a rule stipulating that public debt should not exceed 60 percent of GDP. In practice, these limits are close to the DSF thresholds.
} 
where $d$ is the debt-to-GDP ratio, $g$ is the real growth rate, $\alpha_{i}^{d}$ and $\alpha_{i}^{f}$ are the ratios of domestic and foreign to total debt, $\beta_{i}{ }^{C}$ and $\beta_{i}{ }^{N C}$ are the ratios of concessional and nonconcessional to foreign debt, and $r_{i t}^{d}, r_{i t}^{f}, r_{i t}^{C}$, and $r_{i t}^{N C}$ are the real interest rates on domestic, foreign, concessional and non-concessional loans respectively. $\Delta \varepsilon$ is the real exchange rate depreciation. Given the dearth of data on contingent liabilities, the remaining unexplained components of debt dynamics — the so-called stock-flow adjustments $(S F A)$ - are used as a proxy (see Appendix II for definitions and assumptions).

The primary balance $p b_{i t}$ captures the response of fiscal policy to shocks:

$$
p b_{i t}=f\left(X_{i t}\right)+\varepsilon_{i t},
$$

where $X$ includes macroeconomic variables driving fiscal behavior. The fiscal reaction function linking the primary balance with its macroeconomic determinants is estimated using a panel of 27 LICs (see Section IV). Additionally, we introduce a fiscal capacity ceiling on the primary balance to guarantee that the fiscal reaction function remains plausible in light of past experience (see Appendix III for more details).

Following Celasun, Debrun, and Ostry (2007), debt is forecast by means of a stochastic approach. The model incorporates three sources of risk: fiscal policy shocks, reflecting expenditure slippages or revenue shortfalls ( $\varepsilon$ in equation 1.2); budget's sensitivity to macroeconomic (growth, terms of trade) and financial developments (foreign loan disbursements); and the direct impact of macroeconomic shocks (growth, the exchange rate, and interest rates) on debt dynamics. A large number of debt trajectories over a six-year horizon are derived for each country by combining the shocks to the variables with the fiscal policy behavior and contingent liabilities, as described in equation 1.1. The resulting "fan charts" give the probability of exceeding the debt ceiling for a starting debt level. The "safe debt" is then calculated iteratively by adjusting the starting point until the probability of exceeding the ceiling in the event of adverse shocks is below 5 percent. ${ }^{10}$ Figure 13 shows an illustrative example where the actual debt is below the "safe debt" and, thus, the country has fiscal space. The step-by-step approach outlining the iteration procedure is explained in Appendix III.

Figure 13. Illustration of Fiscal Space ${ }^{1}$ (Percent of GDP)

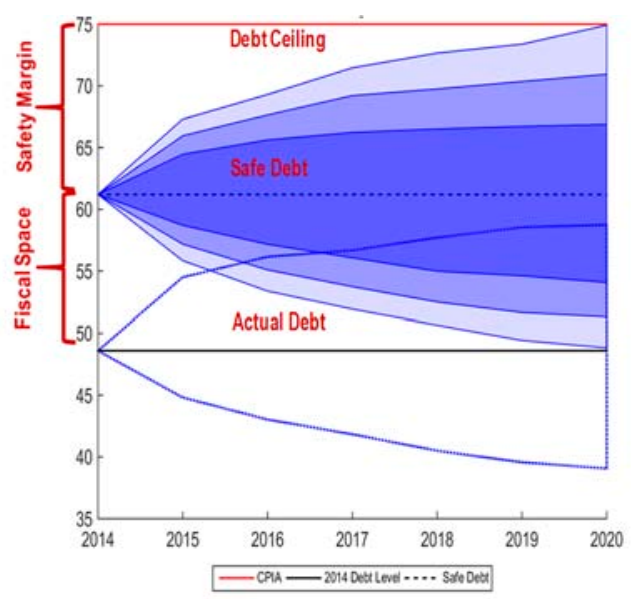

Source: IMF's staff calculations.

${ }^{1}$ Estimates are based on the distribution of historical shocks for Kenva.

${ }^{10}$ That probability can of course be modified to reflect different levels of risk tolerance. 
A few things are important to note:

- Generation of shocks. Ideally, we would like to estimate an unrestricted VAR for each country to describe the joint dynamics of the variables needed to project public debt. Unfortunately, quarterly data are rarely available for LICs and the annual series have a relatively short time span, making it impossible. Estimating a panel VAR is also not a suitable option as we would be imposing the same coefficients across all countries and, therefore, not capture the heterogeneity in our sample. The alternative adopted here is to calibrate country-specific multivariate normal distributions around the historical means of the variables. Country-specific shocks are then sampled directly from the distribution rather than from the VAR. A disadvantage of this approach is that it cannot account for persistence, but the benefit is that one can include a large set of variables since the correlations between every pair of variables are mutually independent. ${ }^{11}$

- $\quad$ Tail risks. An important feature in LICs is their exposure to the emergence of fat tails or asymmetric shocks. To account for some of these dynamics, alternative simulations are run considering a Student's t-distribution (see Appendix III for the comparison between the Student's t and the multivariate normal distributions).

- $\quad$ Policy scenarios. This paper's framework provides flexibility to run scenario analysis. For example, one can change the assumptions on $\alpha^{d}, \alpha^{f}, \beta^{C}$, and $\beta^{N C}$ to explore the implications of shifting the financing mix towards non-concessional loans. Also, the trade-off involved in public investment decisions can be analyzed by modifying the growth distribution assumptions. Section V looks at some of these issues.

\section{Fiscal Behavior}

To capture the endogenous response of fiscal policy to macroeconomic and fiscal shocks, we estimate empirically a fiscal reaction function for an unbalanced panel of 27 LICs over the period 2003-13. The baseline specification takes the form:

$$
\begin{aligned}
& p b_{i t}=\beta_{0}+\delta p b_{i, t-1}+\gamma d_{i, t-1}+x_{i t}^{\prime} \beta_{1}+e_{i t} \\
& e_{i t}=\alpha_{i}+v_{i, t} \\
& \alpha_{i} \sim N\left(0, \sigma_{\alpha}^{2}\right) \text { and } v_{i t} \sim N\left(0, \sigma_{v}^{2}\right)
\end{aligned}
$$

where $p b_{i t}$ denotes the primary balance, $d_{i, t-1}$ is the lagged gross public debt ratio, and $x_{i t}$ is the vector of regressors reflecting specific features of fiscal policy in LICs. We include the

\footnotetext{
${ }^{11}$ VAR shocks are drawn only from the unexplained part of each variable, hence the variance of the shocks themselves is smaller in the VAR than that in the multivariate distribution. Whether VAR coefficients project altogether larger or smaller forecast values of the respective series depends on the estimated coefficients. There might be constellations of coefficients that keep the r-g and exchange rate combinations more favorable for the debt projections than draws from the multivariate distribution, in turn keeping the bands narrower.
} 
terms-of-trade gap interacted with dummy variables for mineral and non-mineral exporters to capture the importance of commodity prices. ${ }^{12}$ Disbursements of public and publiclyguaranteed external debt are also included as a proxy for financing constraints. A negative coefficient for this variable would suggest that when external financing is not available, LICs are unable to substitute it with other forms of financing and, thus, are forced to consolidate. Finally, a dummy variable controls for the years in which countries received debt relief.

The results presented in Table 1 show that the primary balance tends to be persistent and sensitive to changes in the terms of trade, albeit that sensitivity is only significant in the case of mineral exporters. ${ }^{13}$ This suggests that, even if fiscal policy is typically procyclical among commodity producers (IMF 2015d), deficits actually improve during commodity booms. ${ }^{14}$ We also find evidence of financing constraints being binding in LICs: the coefficient of external disbursements is negative and less than one in absolute value in all specifications, implying that reductions in external financing cannot be fully offset by increases in domestic funding. There is no conclusive evidence, however, that fiscal behavior changes significantly following decision or completion points under HIPC (Table 1, column 4) or after gaining access to international financial markets (Table 1, column 5). On the other hand, aid receipts (proxied by grants) are found to be a significant determinant of the primary balance with a positive sign. ${ }^{15}$ This could indicate that aid is in practice a substitute for other forms of financing (e.g., borrowing), thereby, reducing the deficit.

Several differences are worth noting relative to the findings of the literature for advanced and emerging market economies:

- $\quad$ Response to debt increases. The coefficient on the lagged debt ratio is found to be statistically insignificant in most specifications, suggesting fiscal policy in LICs does not react to public debt developments in a stabilizing fashion. This contrasts with the literature, which typically finds positive and significant coefficients for advanced (Mendoza and Ostry 2008) and emerging market economies (Celasun, Debrun, and Ostry 2007; and Abiad and Ostry 2005). This result, however, should not necessarily be taken as evidence that debt levels in LICs will spiral out of control. As noted by Bohn (1998), the debt ratio can be stable when the interest rate-growth differential is negative, as it is usually the case in LICs, even if fiscal behavior is not responsive to

\footnotetext{
${ }^{12}$ For the definition and sources of variables, see Appendix I. For a discussion on the specification of the fiscal reaction function, econometric issues, and robustness checks, see Appendix IV.

${ }^{13}$ The persistence is, however, lower than what other studies have found for advanced and emerging market economies (Debrun, Jarmuzek, and Shabunina 2017; and IMF 2016e) and low income countries (Adedeji and Williams 2007).

${ }^{14}$ This is consistent with the literature which typically finds a positive correlation between commodity prices and primary balances (see, Abiad and Ostry 2005; Celasun, Debrun, and Ostry 2007; and Ghosh and others 2013).

${ }^{15}$ Generally, we would expect aid receipts to be a more important determinant of primary balances in fragile countries and small states, which are excluded from our sample. Therefore, in the interest of parsimony, we exclude this variable from our baseline specification.
} 
changes in debt. One also has to acknowledge that the sample used to estimate the fiscal reaction function covers a period in which many countries used the "space" created by debt relief to undertake development spending. Thus, it is not surprising that primary balances were not responding to increases in debt. Interestingly, once we control for HIPC, the coefficient on debt becomes significant and of similar in magnitude to other studies (Table 1, column 4). ${ }^{16}$

- $\quad$ Stabilization role of fiscal policy. Notwithstanding measurement problems regarding the cyclical position, LICs do not appear to use fiscal policy as a countercyclical tool as indicated by the insignificant coefficient on the output gap (Table 1, column 2). As a matter of fact, booms and busts in terms of trade appear to be more relevant in explaining fiscal behavior in mineral exporters. A possible explanation is that financing constraints may be the dominant force and, thus, LICs spend when they get the financing irrespective of the cyclical position. ${ }^{17}$

- Non-linearity. There is also no evidence of non-linearities in the response of fiscal policy to debt: i.e., the primary balances do not change even for high levels of public debt (Table 1, column 3). ${ }^{18}$ This is contrast with the estimates for advanced and emerging market economies (Ghosh and others 2013; and Celasun, Debrun, and Ostry 2007). A potential explanation is that LICs may have received debt relief when debt reached distressed levels without significantly altering their fiscal behavior. However, data constraints do not allow us to test this hypothesis.

\section{Results}

This section aims to illustrate the application of the methodology proposed in this paper to a sample of 26 LICs for which data are available and make inferences about their potential fiscal space. Alternative simulations are run on a country-by country basis to show the sensitivity of the results to different assumptions regarding uncertainty and policies. ${ }^{19} \mathrm{We}$ first start by estimating fiscal space when the macroeconomic conditions, financing mix, and fiscal behavior are described by historical patterns (baseline). We then show how changes to those assumptions can significantly increase or decrease the estimated space, underscoring

\footnotetext{
${ }^{16}$ To factor this in, we use a fiscal reaction function with a positive coefficient on debt as an alternative specification in our simulations.

${ }^{17}$ Geiregat, Kaffo Melou, and Sumlinski (2014) find, however, some evidence of procyclical behavior for a different sample of LICs and time period from the one used in this paper. This is still consistent with our prior that financing constraints may determine fiscal behavior.

${ }^{18}$ Estimates, not reported here, show the spline term to be insignificant for levels of debt ranging from 40 to 60 percent of GDP.

${ }^{19}$ The debt ceiling in all these simulations is taken from the CPIA-based debt thresholds in the LIC DSF framework (49 percent of GDP for low capacity countries; 62 percent of GDP for medium capacity countries; and 75 percent of GDP for high capacity countries). Country-specific results are aggregated into two groups: mineral and non-mineral countries.
} 
the difficult trade-offs faced by LICs. Results are based on country-specific simulations estimated

\section{Baseline and macroeconomic uncertainty}

Under our baseline, fiscal space in LICs is estimated to be in the double digits, with the median value reaching up to 16 percent of GDP for the full sample. ${ }^{20}$ The space for mineral exporters is more than 5 percentage points of GDP below other LICs (Figure 14, dark blue bar), reflecting their exposure to commodity shocks and the associated growth impact. The implied safety margins below the debt ceilings range from 7 to 10 percent of GDP. One caveat is that the distribution of shocks used in this simulation is based on historical data for 2003-14, a period characterized by relative stability and favorable macroeconomic conditions among LICs. However, the potential for extreme shocks should not be ignored given the heightened global uncertainty going forward. To explore the sensitivity of our results to economic volatility we run three alternative simulations:

Figure 14. LICs: Fiscal Space ${ }^{1}$

(Percent of GDP, median)

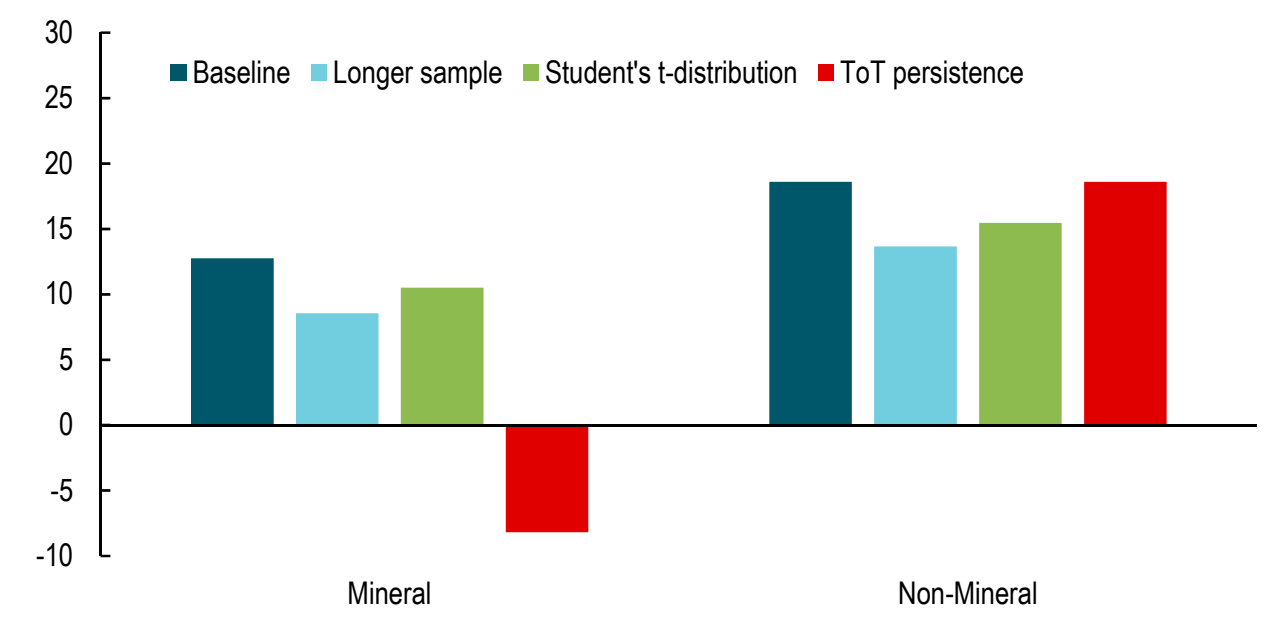

Sources: IMF, World Economic Outlook; and IMF staff estimates.

${ }^{1}$ Simulations are based on a sample of 26 LICs (see Appendix I).

- Longer sample period. For most countries, data are available for a time horizon starting as early as 1996. The dispersion of macroeconomic shocks based on this longer sample is higher than under the baseline, reducing the estimated fiscal space by about a third. The impact is particularly severe among mineral exporters, reflecting their vulnerability to downward movements in commodity prices (see below).

\footnotetext{
${ }^{20}$ All results presented in this section are based on a 5 percent probability of breaching the debt threshold. Assuming a higher risk tolerance will yield a larger fiscal space. For example, under the baseline scenario and assuming a 20 percent probability of breaching the threshold, the average fiscal space increases to 19 percent of GDP.
} 
- $\quad$ Stochastic simulations based on tail events. When shocks are drawn from a multivariate Student's t-distribution, fiscal space is up to 18 percent below the baseline. ${ }^{21}$ This estimate is still higher than that from the longer sample period, suggesting that macroeconomic outcomes during the 1990s were worse than the extreme events over the last decade.

- $\quad$ Persistent terms of trade shocks. Shocks to commodity prices are often large and persistent with swings that can reach as much as 80 percent for as long as a decade (IMF 2015d). From that perspective, focusing on the 2003-14 period to simulate shocks to the terms of trade may not be very meaningful for mineral exporters. For comparison purposes, we assume instead a persistently negative average terms-oftrade gap of 15 percent. Although extreme, this is not an unreasonable assumption as the six major commodity producers in our sample have experienced shocks at least as large as the one assumed here for about 20 percent of the time since 1970. The implications for mineral exporters are huge with fiscal space turning negative (Figure 14 , red bar). This result is, however, not surprising particularly in view of the massive revenue losses and recent widening of fiscal deficits among oil exporters (IMF 2016d and 2016f).

\section{Fiscal behavior}

So far, our simulations have assumed that the fiscal behavior was dictated by historical patterns as described in the fiscal reaction function (Table 1, column 1). A shortcoming of this approach is that fiscal policy does not respond to changes in debt. However, at a time when debt in many countries is rising at a fast clip prompting them to cut spending and deficits, this assumption may not be realistic. Thus, two alternatives are considered. First, fiscal policy is assumed to respond to changes in debt. In practical terms this is implemented by introducing a positive coefficient for the lagged debt term in the baseline specification of our fiscal reaction function. The second option is to assume that the primary balance is set at the level that stabilizes debt as of 2014. A comparison across the different assumptions show that, on average, the debt stabilizing assumption results in the lowest primary deficits over the forecast horizon - about 55 percent below the baseline (Figure 15). Not surprisingly, the improved fiscal performance under the two alternatives results in a higher fiscal space20 percent higher in the case of mineral exporters and about half of that in the rest of LICs (Figure 16).

\footnotetext{
${ }^{21}$ The Student's t-distribution allows for a higher degree of kurtosis than the normal distribution. In this case, more of the macroeconomic variance is the result of infrequent extreme deviations, as fatter tails allow for more draws from outliers in the underlying data (see Appendix III for a graphical example).
} 
Table 1. Estimation Results for Fiscal Reaction Function

\begin{tabular}{|c|c|c|c|c|c|c|}
\hline Specification & $\begin{array}{c}(1) \\
\text { Baseline }\end{array}$ & $\begin{array}{c}\text { (2) } \\
\text { Output } \\
\text { Gap }\end{array}$ & $\begin{array}{c}\text { (3) } \\
\text { Non- } \\
\text { Linear }\end{array}$ & $\begin{array}{c}\text { (4) } \\
\text { Post-HIPC } \\
\text { Decision }\end{array}$ & $\begin{array}{c}\text { (5) } \\
\text { Market } \\
\text { Access }\end{array}$ & $\begin{array}{l}\text { (6) } \\
\text { Aid }\end{array}$ \\
\hline Lagged primary balance & $\begin{array}{c}0.125 \\
(0.048)^{\star \star \star}\end{array}$ & $\begin{array}{c}0.128 \\
(0.05)^{\star * *}\end{array}$ & $\begin{array}{c}0.125 \\
(0.043)^{\star \star \star}\end{array}$ & $\begin{array}{c}0.126 \\
(0.042)^{\star \star *}\end{array}$ & $\begin{array}{c}0.121 \\
(0.046)^{\star \star \star}\end{array}$ & $\begin{array}{c}0.09 \\
(0.05)^{*}\end{array}$ \\
\hline Lagged debt (LD) & $\begin{array}{c}0.009 \\
(0.012)\end{array}$ & $\begin{array}{c}0.009 \\
(0.011)\end{array}$ & $\begin{array}{l}-0.001 \\
(0.037)\end{array}$ & $\begin{array}{c}0.046 \\
(0.02)^{\star \star}\end{array}$ & $\begin{array}{c}0.003 \\
(0.011)\end{array}$ & $\begin{array}{l}-0.001 \\
(0.015)\end{array}$ \\
\hline Debt spline (50\% GDP) & & & $\begin{array}{c}0.014 \\
(0.024)\end{array}$ & & & \\
\hline LD* Post HIPC dec. dum. & & & & $\begin{array}{l}-0.034 \\
(0.029)\end{array}$ & & \\
\hline LD*market access dummy & & & & & $\begin{array}{l}-0.138 \\
(0.107)\end{array}$ & \\
\hline TOT gap (mineral. exp.) & $\begin{array}{c}0.094 \\
(0.049)^{*}\end{array}$ & & $\begin{array}{c}0.089 \\
(0.052)^{*}\end{array}$ & $\begin{array}{c}0.095 \\
(0.054)^{*}\end{array}$ & $\begin{array}{c}0.095 \\
(0.048)^{\star \star}\end{array}$ & $\begin{array}{c}0.05 \\
(0.065)\end{array}$ \\
\hline TOT gap (non-min. exp.) & $\begin{array}{l}-0.021 \\
(0.024)\end{array}$ & & $\begin{array}{l}-0.023 \\
(0.025)\end{array}$ & $\begin{array}{l}-0.022 \\
(0.025)\end{array}$ & $\begin{array}{l}-0.021 \\
(0.024)\end{array}$ & $\begin{array}{l}-0.024 \\
(0.022)\end{array}$ \\
\hline Output gap (min. exp.) & & $\begin{array}{c}0.84 \\
(1.069)\end{array}$ & & & & \\
\hline Output gap (n-min. exp.) & & $\begin{array}{c}0.152 \\
(0.338)\end{array}$ & & & & \\
\hline External disbursements & $\begin{array}{c}-0.397 \\
(0.238)^{\star}\end{array}$ & $\begin{array}{c}-0.395 \\
(0.234)^{\star}\end{array}$ & $\begin{array}{c}-0.785 \\
(0.213)^{\star \star \star}\end{array}$ & $\begin{array}{c}-0.607 \\
(0.317)^{\star}\end{array}$ & $\begin{array}{l}-0.349 \\
(0.269)\end{array}$ & \\
\hline Grants & & & & & & $\begin{array}{c}0.315 \\
(0.134)^{\star *}\end{array}$ \\
\hline Debt relief dummy & $\begin{array}{c}1.419 \\
(0.71)^{\star \star}\end{array}$ & $\begin{array}{c}1.437 \\
(0.669)^{\star *}\end{array}$ & $\begin{array}{c}1.409 \\
(0.756)^{*}\end{array}$ & $\begin{array}{c}1.33 \\
(0.75)^{\star}\end{array}$ & $\begin{array}{c}1.346 \\
(0.692)^{*}\end{array}$ & $\begin{array}{l}-0.062 \\
(0.663)\end{array}$ \\
\hline Post HIPC dec. dummy & & & & $\begin{array}{c}1.646 \\
(1.2)\end{array}$ & & \\
\hline Market access dummy & & & & & $\begin{array}{c}3.36 \\
(4.09)\end{array}$ & \\
\hline Constant & $\begin{array}{l}-0.532 \\
(0.734)\end{array}$ & $\begin{array}{c}-0.531 \\
(0.96)\end{array}$ & $\begin{array}{l}0.843 \\
(0.92)\end{array}$ & $\begin{array}{l}-1.58 \\
(1.42)\end{array}$ & $\begin{array}{l}-0.237 \\
(0.77)\end{array}$ & $\begin{array}{c}-2.86 \\
(0.84)^{\star * *}\end{array}$ \\
\hline$A R(2)$ test $p$-value & 0.377 & 0.631 & 0.384 & 0.373 & 0.374 & 0.512 \\
\hline Hansen test $p$-value & 0.335 & 0.1 & 0.19 & 0.172 & 0.11 & 0.539 \\
\hline Instruments & 20 & 16 & 16 & 16 & 22 & 17 \\
\hline Observations & 292 & 292 & 292 & 292 & 292 & 292 \\
\hline Countries & 27 & 27 & 27 & 27 & 27 & 27 \\
\hline Years per country (avge.) & 10.81 & 10.81 & 10.81 & 10.81 & 10.81 & 10.81 \\
\hline
\end{tabular}

Notes: Dependent variable is gen. govt. primary balance (percent of GDP) in all specifications and the estimator is Blundell-Bond System GMM. 'TOT' denotes the terms of trade; 'min. exp.' are mineral exporting countries; 'Post HIPC dec. dum.' denotes a dummy variable indicating that a country has passed the decision point under the Heavily Indebted Poor Countries Initiative. The 'Market access dummy' indicates whether a country has issued a Eurobond. Robust standard errors are reported in parentheses. Symbols ${ }^{* *},{ }^{* *}$ and * denote statistical significance at 1 percent, 5 percent, and 10 percent levels respectively. 
Figure 15. LICs: Alternative Assumptions on Fiscal Behavior ${ }^{1}$

(Percent of GDP)

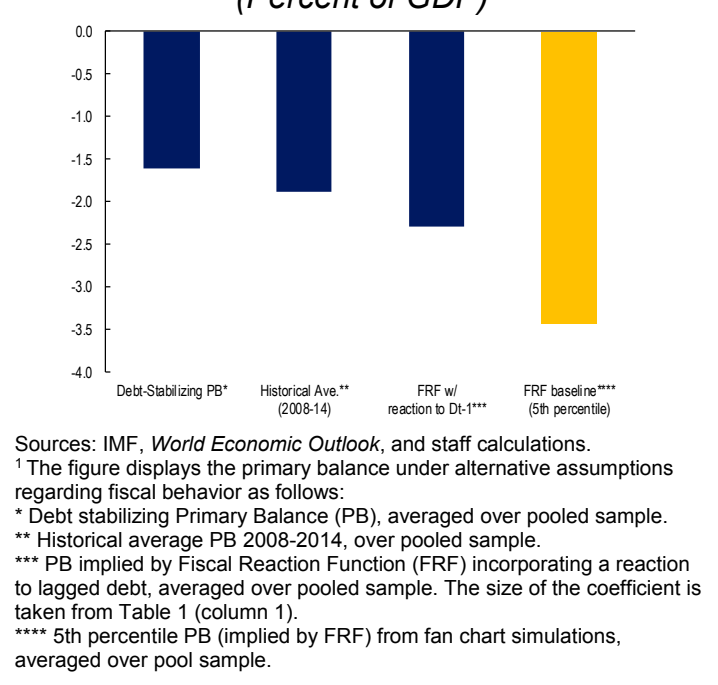

Figure 16. LICs: Fiscal Space under Different Fiscal Behavior ${ }^{1}$ (Percent of GDP, median)

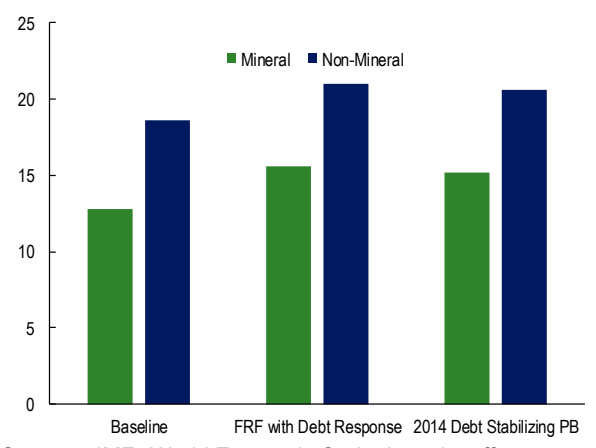

Sources: IMF, World Economic Outlook, and staff calculations.

'Simulations are based on a sample of 26 LICs. PB: primary balance; FRF: fiscal reaction function.

\section{Financing mix and the real exchange rate}

As discussed in section II, increasing reliance on non-concessional external and domestic financing may raise the interest burden. Compounding this effect, a reversal of the real exchange rate appreciation witnessed over the last decade could potentially contribute to a significant increase in the debt service depending on the financing mix. The obvious conclusion is that access to new sources of funding may ease the financing constraints faced by LICs, but it also comes with increased risks. To illustrate the trade-offs implied by the evolving financing landscape, we simulate several scenarios taking as given the distribution of interest rates:

- $\quad$ Changing the financing mix. Substituting half of the concessional loans with nonconcessional external financing results in a significant decline in fiscal space, particularly among non-mineral exporters where the drop is close to 25 percent (Figure 17). On the other hand, replacing external with domestic financing (while keeping the share of concessional loans constant) does not have as much of an impact on fiscal space (non-mineral exporters) or even increases it (mineral exporters).

- Real exchange rate depreciation. Taking the financing mix as given but assuming an average annual real depreciation of 4 percent reduces fiscal space up to 72 percent. $^{22}$ A switch to external financing can amplify this effect, shrinking fiscal space to a meager 2 percent of GDP. On the other hand, the effect of the real depreciation can be mitigated by substituting external with domestic financing. These results highlight the conflicting forces at play as domestic interest rates tend to be higher than external ones, but exchange rate volatility could potentially make external non-concessional loans costlier.

\footnotetext{
${ }^{22}$ As illustrated in Figure 4, the annual real exchange appreciation between 2005 and 2014 was about 2 percent of average but exceeded 4 percent for the countries in the upper quartile of the distribution.
} 
Figure 17. LICs: Fiscal Space under Different Assumptions on Financing Mix and the Real Exchange Rate ${ }^{1}$

(Percent of GDP, median)

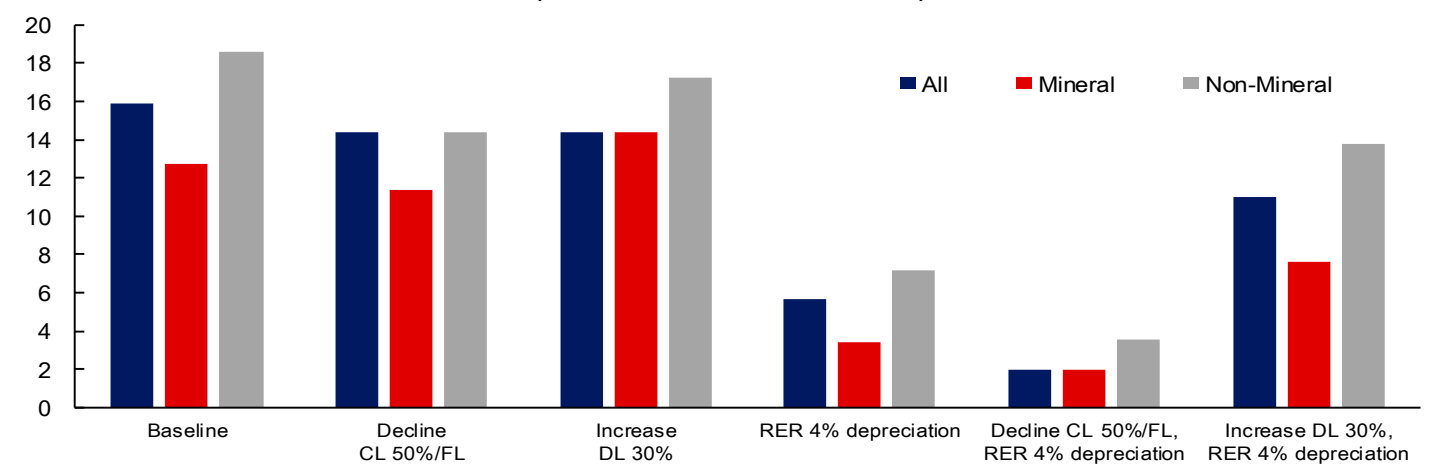

Sources: IMF, World Economic Outlook, and staff calculations.

${ }^{1}$ Simulations are based on a sample of 26 LICs. Five alternative specification are considered: (i) a decline of concessional loans in the share of total foreign loans by 50 percent; (ii) an increase in domestic currency debt of 30 percent, with a corresponding decline of foreign currency debt (the original share of concessional versus non-concessional loans remains constant); (iii) an average real exchange rate depreciation of 4 percent (baseline financing mix); (iv) an average real exchange rate depreciation of 4 percent accompanied by a decline in concessional loans of 50 percent (scenario i); and (v) an average real exchange rate depreciation of 4 percent combined with an increase in domestic debt by 30 percent (scenario ii). CL - concessional loans, DL - domestic loans, FL - foreign loans, RER - real effective exchange rate.

The estimated fiscal space can also fluctuate widely depending on the interest differential between concessional and non-concessional loans. Understanding these dynamics is particularly important now when the normalization of monetary policy in the U.S. is expected to result in tighter financing conditions in LICs. Figure 18 illustrates the implications of such scenario by estimating the fiscal space for a generic country under different assumptions on interest and exchange rates but taking the financing mix as given. Overall, the simulations suggest that, even if the real exchange rate was constant, fiscal space could plunge by more than 70 percent if the relative costs of non-concessional sources of financing were to increase from $100 \mathrm{bps}$ to $350 \mathrm{bps}$. Under this scenario, fiscal space can even turn negative if the real exchange rate depreciates by 3 percent or more.

Figure 18. Fiscal Space, Interest Rate Differentials, and the Exchange Rate ${ }^{1}$

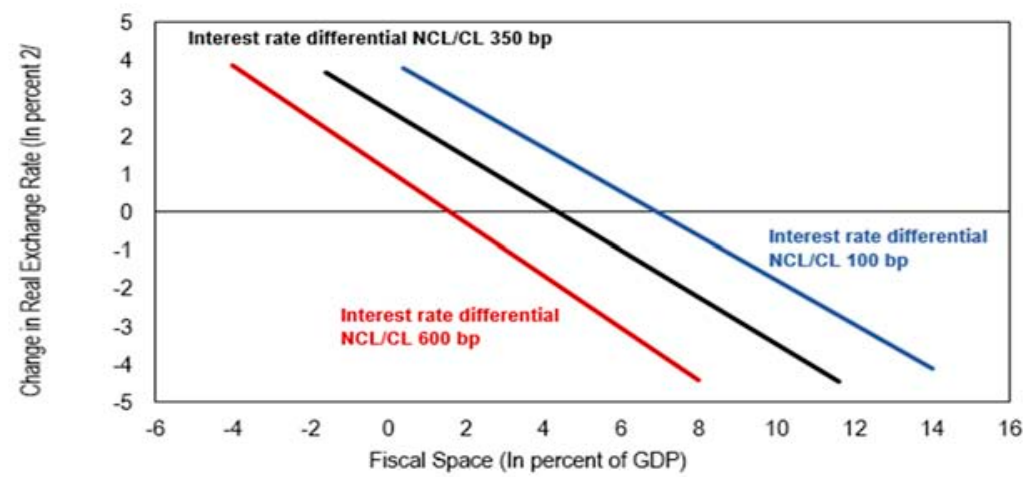

Source: IMF staff calculations.

${ }^{1}$ The simulation is based on a generic country (macroeconomic volatility, original debt level and debt ceiling are based on Kenya).

The share of domestic to foreign debt is 50 percent, and the ratio of concessional loans (CL) to non-concessional loans (NCL) in the

foreign financing mix is 40 percent.

${ }^{2}$ Positive (negative) numbers indicate depreciation (appreciation). 


\section{Policy scenarios}

The simulations described above imply that the fiscal space available in LICs is dwarfed by the incremental annual spending needs that must be financed by the public sector to achieve the SDGs - estimated at around 30 percent of GDP (Schmidt-Traub 2015). Fiscal space is, however, a dynamic concept that depends not only on current but also future conditions. Government policies can affect both through various channels that enhance the resilience to shocks. Two examples of particular relevance for LICs are the scaling up of public investment and domestic revenue mobilization (DRM). The following two scenarios illustrate how these policies can actually increase fiscal space:

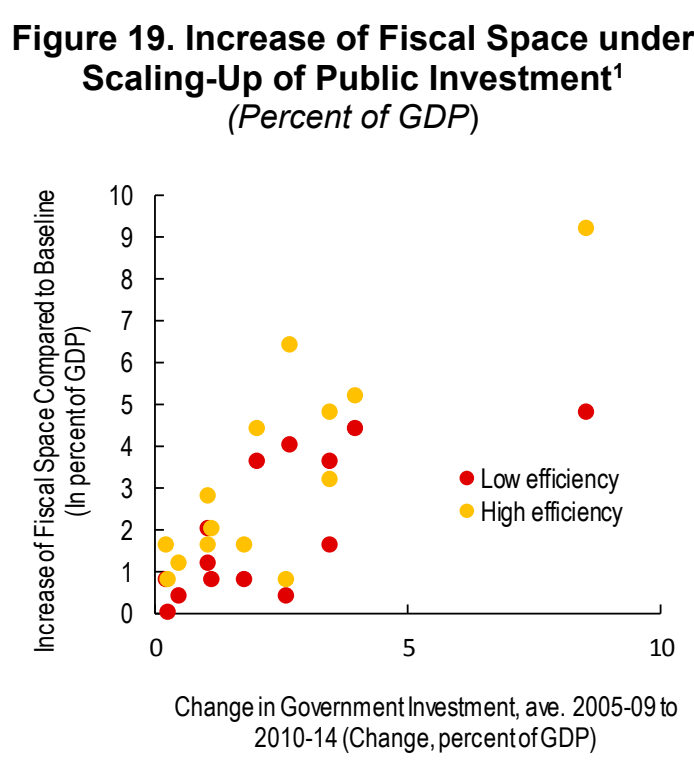

- $\quad$ Scaling-up of public investment. Public infrastructure has gradually increased in many LICs over the last fifteen years, helped by a favorable global

Sources: IMF, World Economic Outlook, and staff calculations. ${ }^{1}$ The sample comprises fifteen countries where there was a scaling up of public investment over the last decade. Assumed multipliers are 0.6 for the lower efficiency and 1.2 for the higher efficiency. environment and debt relief (IMF 2016e). Empirical studies suggest that the productivity of public capital in LICs is significantly higher than the marginal costs of funds under normal financing conditions (Gupta and others 2014), implying this policy can de facto augment fiscal space thanks to a large growth dividend. Nevertheless, the long-term multiplier of public investment would depend on its efficiency. To analyze these dynamics, we run a scenario where the forecast growth rate of each country depends on the magnitude of the public investment increase during the last decade. We assume two alternative efficiency levels of public investment with associated fiscal multipliers of 1.2 and $0.6 .{ }^{23}$ In this scenario, fiscal space can increase significantly with the payoffs for the higher efficiency almost 80 percent larger (Figure 19). Notwithstanding shortcomings in this analysis-issues

Figure 20. Increase of Fiscal Space under DRM $^{1}$ (Percent of GDP)

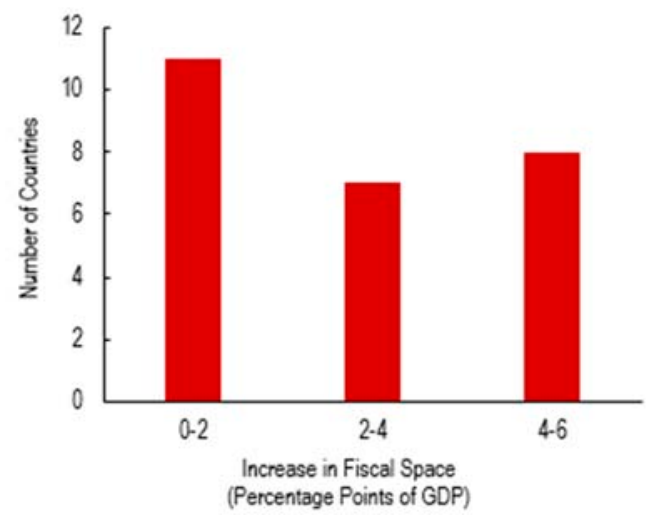

Sources: IMF, World Economic Outlook, and staff calculations.

${ }^{1}$ The scenario assumes that fiscal revenue increase permanently by $2 \frac{1}{2}$ percent of GDP, the primary balance improves by $1 / 2$ percent of GDP, and the additional public investment is of high quality (multiplier of 1.2).

\footnotetext{
${ }^{23}$ Shen, Yang, and Zanna (2015) calculate the cumulative multiplier of external-debt financed capital spending to be 1.14 over a 10 -year horizon when efficiency is relatively high.
} 
such as country-specific efficiency, absorption capacity, and crowding-out of private investment are not considered - these results underscore the benefits associated not only with the scaling-up of public investment but also of management systems that improve its efficiency.

- $\quad$ DRM. Revenues in non-mineral exporters increased by $2 \frac{1}{2}$ percent of GDP in 2010 15 relative to 2005-10. A simple econometric analysis for a panel of LICs shows that the primary balance increases by 0.2 percent of GDP for every one percentage point increase of revenues, suggesting that such DRM could expand fiscal space even if some money is spent. ${ }^{24}$ Assuming that this trend continues over the next five years, one would expect the primary balances to improve by about $1 / 2$ percent of GDP. In a scenario where remaining additional revenue is being spent in high-efficiency public investment, fiscal space would increase by as much as six percent of GDP (Figure 20).

\section{Conclusions}

Although there is significant uncertainty about the incremental annual spending needs required to achieve the SDGs in LICs, they are likely to be very large, running in the hundreds of billions of dollars according to some estimates. Undoubtedly, a significant part of this spending will fall onto the public sector, raising the questions of whether LICs can be expected to do it all, and what it will take to get there. In this paper, we have developed a new metric of fiscal space in LICs that allows us to look at these questions. Our approach takes account of the trade-offs between the higher public spending and the risks associated with increasing public debt while controlling for various sources of uncertainty. The basic premise is that, for a given debt limit or ceiling (whatever that might be), there is a "safe debt" level that ensures the country does not breach that limit with a high probability. The distance between the current and the safe debt level then tells us how large fiscal space is.

The evidence presented in this paper shows that fiscal policy in LICs is predominantly explained by the access to financing rather than cyclical considerations, and that exchange rates and terms of trade are major sources of volatility. Moreover, fiscal space varies widely depending on the nature of uncertainty. Illustrative simulations suggest that, under a benign scenario with relatively mild shocks, the available fiscal space is in the double digits but will not be enough to meet all the spending needs in LICs. The picture becomes even bleaker under more extreme conditions. In particular, a repeat of the macroeconomic shocks of the 1990s could lower fiscal space by a third while large swings in commodity prices could completely wipe it out in the case of mineral exporters. Our results also imply that fiscal

\footnotetext{
${ }^{24}$ The econometric model relates the level of primary expenditure to the level of revenue and is estimated using rolling five year averages to abstract from cyclical effects. Lagged values of revenue are used as instruments, to address various potential sources of omitted variable bias, including instances where new revenue measures are introduced specifically to fund particular spending projects. Similar results were obtained by estimating the model using data in five-year average blocks (e.g., 2010-14, 2005-09), as well as annual data. Econometric models with the primary balance (in percent of GDP) as the dependent variable were also estimated. For these regressions, lagged values of revenue were again chosen as instruments because of potential endogeneity arising in part because of the mechanical relationship between revenue and the primary balance. The results obtained were broadly consistent with those reported here.
} 
space could shrink by a factor of eight if changes in the financing mix away from concessional loans were accompanied by a reversal of the real exchange rate appreciation witnessed in recent years.

In a world of heightened uncertainty, it is tempting to conclude that the scenarios described above can play out in real life, casting doubts on the feasibility of the SDGs. However, this conclusion fails to account for the policy responses that can alter the resilience to shocks. Our simulations show that improving the efficiency of public investment can go a long way towards widening the available fiscal space. Equally important, a strong domestic revenue base is essential to finance public services and infrastructure spending. Nonetheless, it is worth noting that keeping the trend in domestic revenue mobilization unchanged from recent years will barely make a dent in many countries compared to spending required to achieve the SDGs, underscoring the need for more ambitious objectives. Finally, it is also clear that concessional financing should remain a major source of funding, particularly at a time when tighter financing conditions (brought about by the normalization of rates in the U.S.) can severely constraint the available fiscal space.

A shortcoming of our analysis is that we take the debt limit as given, using as benchmark the debt thresholds from the DSF which some may argue are not reflective of solvency problems. Nevertheless, these thresholds signal levels beyond which countries may be close to debt distress - as measured by debt restructuring, arrears, and outright defaults (IMF and World Bank 2012) — and, in practice, many creditors factor in these limits in their lending decision. Ideally, we should also look at the assets (particularly in resource-rich countries) to assess fiscal space. More generally, the framework takes a pragmatic approach to run policy scenarios in a deterministic way. Integrating this framework in a DSGE model will be a line of future research that could provide much richer insights. 


\section{APPENDiX I. DATA}

\section{Country sample}

Because of data constraints fragile states, small states, Guinea, Mongolia and Uzbekistan were excluded from the sample of LICs. The final sample includes the following countries (mineral-exporters are denoted in bold letters, frontier markets are denoted with a star): Bangladesh*, Benin, Bolivia*, Burkina Faso, Cambodia, Cameroon, Ethiopia, The Gambia, Ghana*, Honduras, Kenya*, Kyrgyz Republic, Laos, Lesotho, Mauritania, Moldova, Mozambique*, Nicaragua, Niger, Nigeria*, Papua New Guinea*, Rwanda, Senegal*, Tajikistan, Tanzania*, Uganda*, Vietnam*, and Zambia*. ${ }^{25}$

\section{Data sources}

- World Economic Outlook (WEO): nominal and real GDP, primary balance, grants, total government debt, local currency-denominated government debt, foreign currency-denominated debt, and terms of trade.

- $\quad$ The World Banks' World Development Indicators (WDI): external disbursements of public and publicly-guaranteed debt, and debt relief.

- $\quad$ LIC Debt Sustainability Database: real interest rates on domestic and foreign debt.

\section{Definitions}

- $\quad$ The primary balance is defined as: non-interest revenue less non-interest expenditure of the general government, adjusted for debt relief (in cases where it has been recorded as revenue).

- $\quad$ The output gap is computed as the percentage difference between the actual level of real GDP and the Hodrick-Prescott filtered trend level.

- $\quad$ The terms of trade gap is the percentage difference between the actual level of terms of trade and the Hodrick-Prescott filtered trend level.

\footnotetext{
${ }^{25}$ Estimates for the fiscal reaction function excluded Lesotho because of data constraints. For simulation purposes The Gambia was also excluded as the public debt was well in excess of the debt ceiling.
} 


\section{APPENDix II. STOCK FLOW AdJUSTMENTS AND CONTINGENT LiABILITIES}

Information on the realization of contingent liabilities in LICs is very scarce. ${ }^{26}$ To measure them, an alternative is to look at the SFAs. However, some adjustments are needed as they also include time of recording (deficits are often measured in accrual terms while debt is a cash concept) and balance sheet effects (Weber 2012). To estimate the proxy for the realization of contingent liabilities, we thus proceed in two steps:

- $\quad$ Fist, SFAs for each country/year are derived from equation (1.1).

- $\quad$ Second, the quantifiable components (balance-sheet effects) are removed to calculate the "residual" SFA. For the balance-sheet effects, we focus on the most relevant items for which information is available, namely debt relief and privatization proceeds. ${ }^{27}$

Figure A2. 1 shows the average annual "residual" SFAs in our sample which, at

Figure A2.1. LICs: Residual Stock-Flow Adjustments ${ }^{1}$ (Percent of GDP)

3.2 percent of GDP, is quite significant. ${ }^{28}$ Privatization proceeds played a rather modest role in SFA developments, most likely owing to the non-exhaustive coverage of the privatization database. Mineral producers have generally higher residuals: the median annual value is $2 \frac{1}{4}$ percent of GDP versus $13 / 4$ percent of GDP in non-mineral producers.

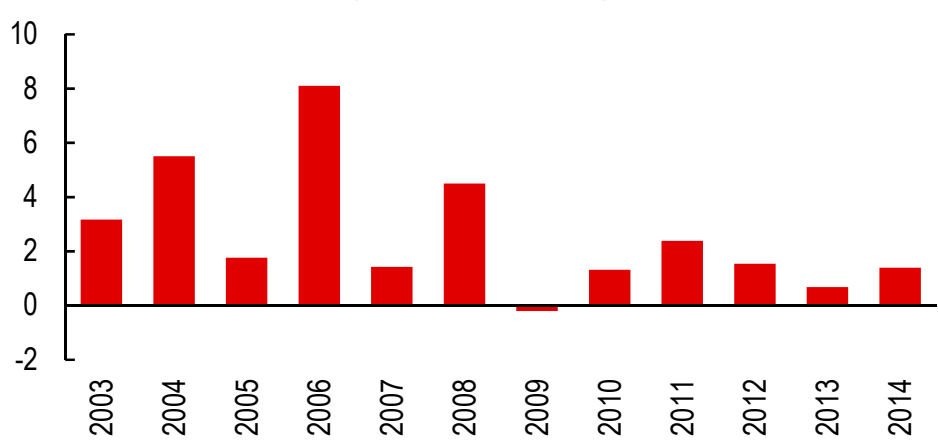

Sources: IMF, World Economic Outlook; Debt Sustainability Analysis database; World Bank, World Development Indicators and privatization database.

${ }^{1}$ Sample comprises 27 LICs. For more details, see Appendix I.

\footnotetext{
${ }^{26}$ Contingent liabilities are government's fiscal obligations that may arise conditional upon the occurrence of particular events (Polackova 1999). The Public Sector Debt Statistics Guide views contingent liabilities as obligations that do not arise unless discrete events occur in the future (IMF 2011; Bova and others 2016).

${ }^{27}$ Note however that this approach presents some limitations, as it assumes that the unexplained part of SFA only captures the realization of contingent liabilities, which may not always be the case. Data on debt relief come from the World Development Indicators, while privatization proceeds are drawn from the World Bank's privatization database.

${ }^{28}$ The minimum value was -68.8 percent of GDP while the maximum stood at 58.4 percent of GDP. The largest contribution of debt relief in explaining the SFAs for the countries in our sample was during 2003-07 (a point in time where many LICs reached the HIPC completion point).
} 


\section{Appendix III. The Stochastic Simulation Model}

\section{Step-by-step methodology}

Adverse shocks are generated for the macroeconomic variables - interest rates (domestic, concessional, and non-concessional), growth rate, exchange rate, terms-of-trade, and foreign loan disbursements - as well as the primary balance..$^{29}$ This set will be called $V G U$ (variables generating uncertainty) hereafter.

The initial debt level that would keep debt below the debt ceiling during the five-year timeframe ${ }^{30}$ with a 95 percent probability is calibrated for each country as follows:

i. $\quad N$ sets of $V G U$ are drawn over the forecast horizon from their multivariate distribution.

ii. $\quad N$ paths of primary balances are then calculated based on equation (1.2) and using these draws. Additionally, we introduce two distinct caps for mineral and non-mineral exporters on the primary balance to ensure the fiscal reaction function yields realistic estimates. Thus, the primary balance level (annual change) in each period is determined by the minimum of the primary balance predicted by the fiscal reaction function and the maximum fiscal balance level (annual change) based on historical data. $^{31}$

iii. $\quad N$ paths for public debt are then calculated based on equation (1.1), the random draws of the $V G U$, the primary balance from step (ii), and an a predefined "residual" SFA. ${ }^{32}$ The size of the SFA varies across countries and is chosen with the following algorithm, which implicitly sets a cap at 3 percent of GDP to avoid bias from outliers and measurement errors:

$$
S F A_{i t}=\left\{\begin{array}{lr}
\max \left[\operatorname{med}\left(S F A_{\text {all }}\right) ; S \bar{F} A_{i}\right], & \text { for all } \overline{S F} A_{i} \leq 3 \\
3 & \text { for all } S \bar{F} A_{i}>3
\end{array}\right.
$$

where $S \bar{F} A_{i}$ is the maximum historical stock-flow adjustment for country $i$. Therefore, the SFA is non-stochastic in our simulations.

\footnotetext{
${ }^{29}$ Shocks to the primary balance are considered are considered through realizations of draws from countryspecific error term $\varepsilon$ in equation (1.2).

${ }^{30}$ The timeframe was chosen in line with the forecast horizon in the World Economic Outlook but can be modified. Nonetheless, there are trade-offs as lengthening the time horizon will increase the uncertainty surrounding the possible debt paths making the fan charts wider.

31 The ceiling is defined as a cross-country median of the maximum five-year moving average of countryspecific primary balances (levels or changes). The resulting ceiling for the primary balance level (annual change) is $4 \frac{1}{4}(5)$ and $1 \frac{1}{4}\left(1 \frac{1}{4}\right)$ percent of GDP for mineral and non-mineral exporters respectively.

${ }^{32}$ Due to data constraints on the financing mix, 2014 is taken as the starting point for the simulations.
} 
iv. If the $95^{\text {th }}$ debt percentile (of the $\mathrm{N}$ simulations) by 2020 lies below (above) a margin of more than 0.4 percent of GDP, the current debt level is increased (decreased) by 0.3 percent and steps (i-iii) are repeated.

Steps (i-iv) are repeated until the $95^{\text {th }}$ percentile of the debt level by 2020 falls into the margin around the CPIA debt threshold: i.e. $D e b t^{95} \in[C P I A-0.4 ; C P I A+0.4]$. That debt level is then the "safe debt". Results presented in this paper are based on $\mathrm{N}=2000$.

\section{The Multivariate Normal and Student's T Distributions}

Shocks are drawn from country-specific multivariate normal distributions described as follows:

$$
\begin{aligned}
x & \square \mathrm{N}_{k}(\mu, \Sigma) \\
& \text { with the k-dimensional mean vector } \\
\mu & =\left(E\left[X_{1}\right], E\left[X_{2}\right], \ldots, E\left[X_{k}\right]\right) \\
& \text { and the } k \times k \text { covariance matrix } \\
\Sigma & =\left(\operatorname{cov}\left(\mathrm{X}_{i}, X_{j}\right)\right), \text { for all } i=1,2, \ldots, k ; j=1,2, \ldots, k
\end{aligned}
$$

where $k$ is the number of variables considered.

One issue with the multivariate normal distribution is that it does not capture tail risk events well, as the bell-shaped density is relatively narrow. As an alternative, we use a multivariate Student's t-distribution, which has heavier tails than the Gaussian distribution, depending on the assumed degrees of freedom (scalar and positive $v$ ) that determines the degree of kurtosis. The larger the degrees of freedom, the closer the t-distribution resembles the normal distribution, converging towards the normal distribution for $v \rightarrow \infty$. The smaller the number of degrees of freedom, the fatter the tails become (Figure A3.1).

Figure A3.1. Student T-Distribution PDF

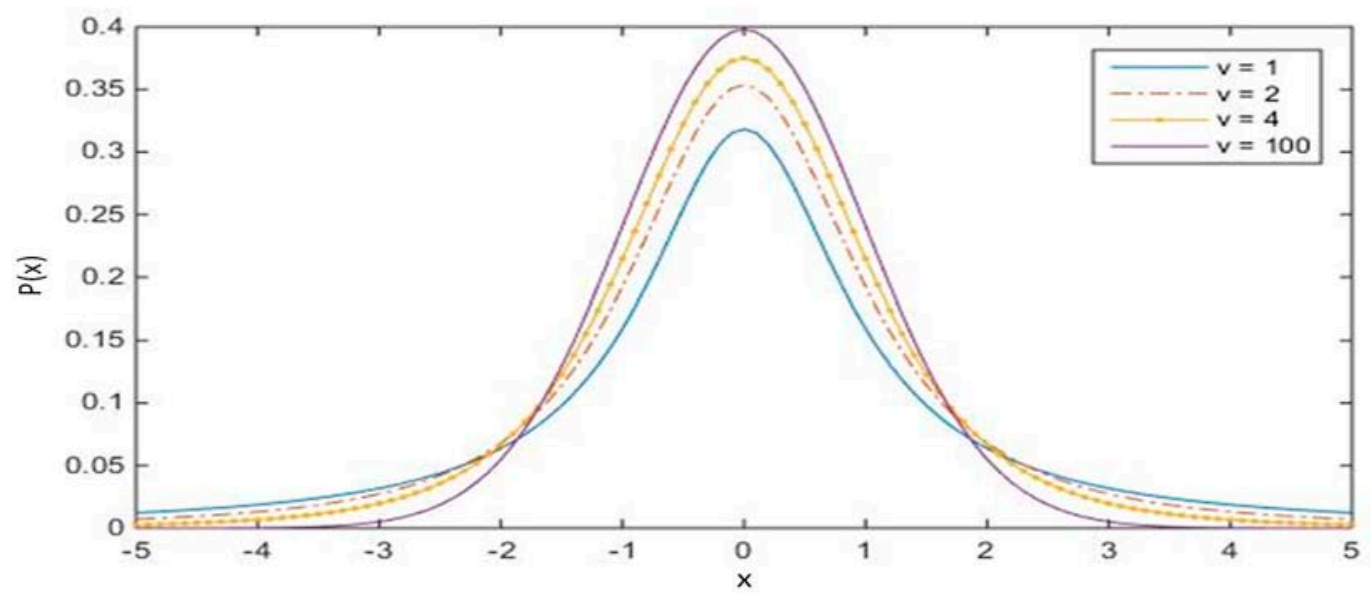

Source: IMF staff calculations. 
In the special case where the degrees of freedom equal 1 , the distribution becomes a multivariate Cauchy distribution. For the purpose of our simulation, we set the degrees of freedom to 4. Figure A3.2 illustrates the random draws for Bolivia's growth rates under a normal and a Student's t-distribution under that assumption.

Figure A3.2. Bolivia: Shocks to the Growth Rate
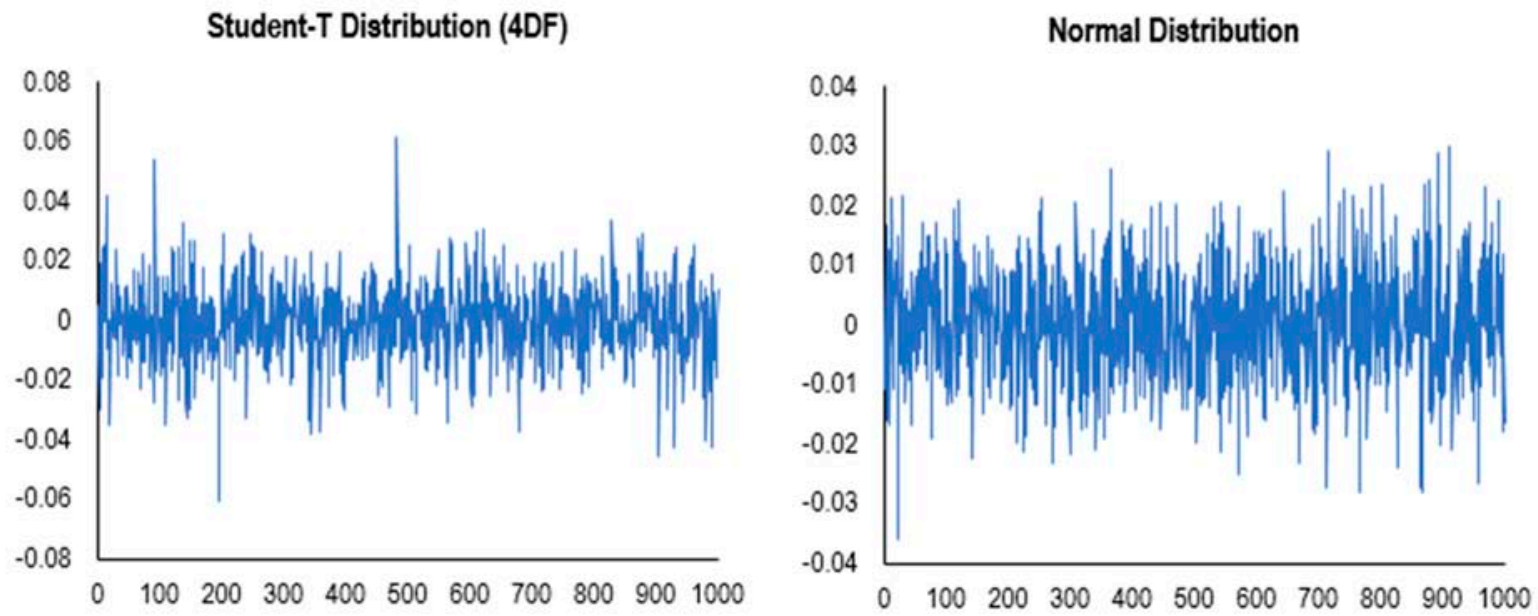

Source: IMF staff calculations.

On a technical note, Matlab has a command to sample from a normalized multivariate Student's t-distribution with zero mean, normalized variances and a pre-defined covariance structure $\Sigma$. Each generalized draw $\Upsilon$ is therefore converted to fit the real data as follows:

$$
X=\mu+\Upsilon \sqrt{\operatorname{diag}(\Sigma)} .
$$




\section{APPENDIX IV. FISCAL REACTION FUNCTION: ECONOMETRIC ISSUES AND ROBUSTNESS CHECKS}

A fiscal reaction function captures the systematic way in which the primary balance reacts endogenously to current economic conditions (the business cycle) and solvency concerns, as reflected in the positive impact of the outstanding stock of public debt (Bohn 1998). Our baseline specification is described as follows:

$$
p b_{i t}=\beta_{0}+\delta p b_{i, t-1}+\gamma d_{i, t-1}+x_{i t}^{\prime} \beta_{1}+e_{i t}
$$

where $e_{i t}=\alpha_{i}+v_{i, t}$ is the error term, with $\alpha_{i} \sim N\left(0, \sigma_{\alpha}^{2}\right)$ the country specific, time-invariant component and $v_{i t} \sim N\left(0, \sigma_{v}^{2}\right)$ the component idiosyncratic to each country and time period.

This equation contains a number of variables that are endogenous to the contemporaneous error term $e_{i t}$ :

- $\quad$ The lagged dependent variable $p b_{i, t-1}$ (lagged primary balance (as a percentage of GDP): It comprises the lagged error term $e_{i, t-1}$, a component of which is the non-time varying $\alpha_{i}$, which is also a component of $e_{i t}$.

- $\quad$ Lagged gross public debt (as a percentage of GDP) $d_{i, t-1}$ : by definition, it is determined by the lagged primary balance $p b_{i, t-1}$ (as a percentage of GDP), as well as by all further lags of the primary balance. The lagged primary balance $p b_{i, t-1}$ depends on $\alpha_{i}$ and is endogenous to $e_{i t}$, as shown above, as do all further lags of the primary balance.

Regressors in $x_{i t}$ may be endogenous to $e_{i t}$, if omitted factors or shocks captured by the $e_{i t}$ error term affect both the primary balance and regressors such as the output gap and disbursements on external public and publicly guaranteed debt.

\section{System Generalized Method of Moments (GMM) Estimator}

The main estimator used in this paper is the System GMM dynamic panel estimator developed by Blundell and Bond (1998). The estimator is based on two types of moment conditions: (i) those relating to the econometric equation in first differences; and (ii) those relating to the econometric equation in levels.

Differencing the econometric equation purges the error term of the time-invariant component $\alpha_{i}$, so that the error term in time $t$ is $v_{i t}-v_{i, t-1}$, an MA(1) process with finite memory. The differenced lagged dependent variable $p b_{i, t-1}-p b_{i, t-2}$ contains $v_{i, t-1}$, as does the differenced lagged debt ratio $d_{i, t-1}-d_{i, t-2}$, because of its dependence on $p b_{i, t-1}$. Moment conditions are constructed by instrumenting for these differenced variables using the second lagged level of the primary balance $p b_{i, t-2}$ and the second lagged level of the debt ratio $d_{i, t-2}$ respectively, which will be exogenous to the differenced error term. Further lagged levels of these variables are also valid instruments. Moment conditions concerning the lagged differences of endogenous variables in $x_{i t}$ (e.g. disbursements of external public debt) are 
constructed by instrumenting using the lagged levels of these variables, as well as exogenous variables (such as the terms of trade gap).

However, a potential drawback of these moment conditions is that lagged levels of variables may be poor instruments for differenced variables, if the endogenous variables themselves are highly persistent. This may be true of variables such as the debt ratio.

Moment conditions associated with the equation in levels seek to overcome this difficulty. They are constructed by using lagged differences of variables as instruments for the endogenous variables of the equation in levels. It is assumed that differencing variables purges the fixed effects, so that the variables will be exogenous to the time invariant component of the error term for the equation in levels $\alpha_{i}$, as well as the idiosyncratic component $v_{i t}$.

Two specification tests are performed following system GMM estimation:

- $\quad$ A Test for Second Order Serial Correlation in the Differenced Error Term: The presence of second order serial correlation of $\left(v_{i t}-v_{i, t-1}\right)$ implies first order serial correlation of the levels $v_{i t}$. The presence of serial correlation of this type may imply that it is inappropriate to use the second lagged level (or further lags) of the primary balance and the debt ratio as instruments for the first lagged differences of these variables, because of the dependence of the lagged primary balance and lagged debt ratio on the serially correlated error term. The null hypothesis for this test is that there is no second order serial correlation of the differenced error term.

- $\quad$ A Hansen Test of Over-identification: This tests the validity of the instruments, under the null hypothesis that instruments are valid.

\section{Generalized Least Squares (GLS)}

An alternative estimator is used as a robustness test, applied to a modified specification:

$$
p b_{i t}=\beta_{i}+\gamma d_{i, t-1}+x_{i t}^{\prime} \beta_{1}+v_{i t}
$$

This equation allows for country specific intercept terms $\beta_{i}$, achieved by adding country dummies (fixed effects) as regressors to the econometric equation. It is assumed that these country specific intercepts capture entirely the time invariant component $\alpha_{i}$ of the error term $e_{i t}$ from the econometric equation estimated with system GMM. This avoids the endogeneity of the lagged debt ratio to the error term $e_{i t}=\alpha_{i}+v_{i, t}$ encountered in the econometric equation estimated with system GMM.

The lagged dependent variable (lagged primary balance) is omitted from the econometric equation. The persistence of the primary balance (as a percentage of GDP) is captured by the error term in this alternative specification, with $v_{i t}$ assumed to be generated by an $\operatorname{AR}(1)$ process: $v_{i, t}=\rho v_{i, t-1}+u_{i t}$, where $u_{i t} \sim N\left(0, \sigma_{i}^{2}\right)$. 
A Feasible Generalized Least Squares (FGLS) estimator is then used to estimate this equation, accounting for serial correlation in the error term. This estimation approach was followed by Abiad and Ostry (2005) and is also similar to the approach taken in Ghosh and others (2013), both of which estimate fiscal reaction functions using panel data.

\section{Robustness checks}

Table A.4.1 presents a range of robustness checks. The first specification presents the baseline excluding the external disbursements term. The key features of the baseline results are robust to this omission: (i) there is persistence of the primary balance; (ii) the lagged debt term is statistically insignificant; and (iii) the terms of trade gap is statistically significant for mineral exporting countries. The second specification omits the external disbursements term and includes the output gap in place of the terms of trade gap. The output gap continues to be statistically insignificant, suggesting that fiscal policy does not react in a counter-cyclical way to stabilize business cycle fluctuations.

Specifications three and four are estimated using the Generalized Least Squares (GLS) estimator, with country dummy variables and an assumed AR(1) error structure, to capture persistence of the primary balance. The lagged dependent variable is not included. GLS estimates for the baseline specification (excluding the lagged primary balance) are presented as specification three. A small, positive and statistically significant coefficient on lagged debt is found using the GLS estimator, compared with the results under the GMM estimator. As discussed in Section V, some simulations are conducted using a fiscal reaction function including a positive response to lagged debt, as an alternative scenario, to allow for this possibility. Specification four shows that the output gap is found to be statistically significant using the GLS estimator, unlike the results obtained using System GMM, indicating that results regarding the importance of the output gap to fiscal policy in LIDCs are not robust.

Specification five presents ranges of coefficients, obtained from a series of System GMM regressions, each with 26 countries (omitting one country sequentially each time).

Coefficient estimates for the lagged primary balance and terms of trade gap (mineral exporting countries) are always positive, suggesting that the results concerning the persistence of the primary balance and the importance of the terms of trade are robust. Similarly, coefficients on external disbursements are always negative and less than one in absolute value, suggesting that reductions in external financing indeed cannot be fully substituted by increases in domestic financing. 
Table A4.1. Estimation Result for the Fiscal Reaction Function: Further Specifications

\begin{tabular}{|c|c|c|c|c|c|}
\hline Specification & $\begin{array}{c}\text { (1) } \\
\text { Baseline } \\
\text { (without ext. } \\
\text { disb.) }\end{array}$ & $\begin{array}{c}\text { (2) } \\
\text { Output Gap } \\
\text { (without ext. } \\
\text { disb.) }\end{array}$ & $\begin{array}{c}(3) \\
\text { Baseline } \\
(G L S) \\
\text { (AR(1) Error } \\
\text { Structure } \\
\text { and Fixed } \\
\text { Effects) } \\
\end{array}$ & $\begin{array}{c}(4) \\
\text { Output Gap } \\
(G L S) \\
\text { (AR(1) Error } \\
\text { Structure } \\
\text { and Fixed } \\
\text { Effects) }\end{array}$ & $\begin{array}{c}\text { (5) } \\
\text { Eliminating One } \\
\text { Country } \\
\text { at a time (range } \\
\text { of coeff. } \\
\text { estimates shown) }\end{array}$ \\
\hline Lagged primary balance & $\begin{array}{c}0.171 \\
(0.056)^{\star \star \star}\end{array}$ & $\begin{array}{c}0.027 \\
(0.069)^{\star *}\end{array}$ & & & $0.109-0.164$ \\
\hline Lagged debt & $\begin{array}{l}0.006 \\
(0.01)\end{array}$ & $\begin{array}{c}0.003 \\
(0.013)\end{array}$ & $\begin{array}{c}0.018 \\
(0.006)^{\star \star \star}\end{array}$ & $\begin{array}{c}0.017 \\
(0.006)^{\star \star \star}\end{array}$ & $0.009-0.021$ \\
\hline TOT gap (min. exp.) & $\begin{array}{c}0.097 \\
(0.051)^{*}\end{array}$ & & $\begin{array}{c}0.093 \\
(0.034)^{\star \star \star}\end{array}$ & & $0.07-0.148$ \\
\hline TOT gap (non-min. exp.) & $\begin{array}{l}-0.024 \\
(0.023)\end{array}$ & & $\begin{array}{c}-0.01 \\
(0.017)\end{array}$ & & $-0.04--0.012$ \\
\hline Output gap (min. exp.) & & $\begin{array}{l}-0.182 \\
(0.42)\end{array}$ & & $\begin{array}{c}0.571 \\
(0.277)^{\star \star}\end{array}$ & \\
\hline Output gap (n-min. exp.) & & $\begin{array}{c}0.568 \\
(0.422)\end{array}$ & & $\begin{array}{c}0.26 \\
(0.069)^{\star \star \star}\end{array}$ & \\
\hline External disbursements & & & $\begin{array}{c}-0.215 \\
(0.078)^{\star \star \star}\end{array}$ & $\begin{array}{c}-0.165 \\
(0.076)^{\star \star}\end{array}$ & $-0.62--0.362$ \\
\hline Debt relief dummy & $\begin{array}{c}1.492 \\
(0.708)^{\star \star}\end{array}$ & $\begin{array}{c}1.467 \\
(0.67)^{\star \star}\end{array}$ & $\begin{array}{c}0.587 \\
(0.221)^{\star \star \star}\end{array}$ & $\begin{array}{c}0.55 \\
(0.216)^{\star \star}\end{array}$ & $0.729-1.518$ \\
\hline Constant & $\begin{array}{c}-1.67 \\
(0.46)^{\star \star *}\end{array}$ & $\begin{array}{c}-1.492 \\
(0.626)^{\star \star}\end{array}$ & $\begin{array}{c}1.239 \\
(1.064)\end{array}$ & $\begin{array}{c}1.24 \\
(1.049)\end{array}$ & $-0.975--0.094$ \\
\hline Estimator & $\begin{array}{l}\text { System } \\
\text { GMM }\end{array}$ & $\begin{array}{l}\text { System } \\
\text { GMM }\end{array}$ & GLS & GLS & System GMM \\
\hline $\operatorname{AR}(2)$ test $p$-value & 0.208 & 0.284 & & & \\
\hline Hansen test $p$-value & 0.211 & 0.343 & & & \\
\hline Instruments & 18 & 18 & & & \\
\hline Observations & 292 & 292 & 292 & 292 & \\
\hline Countries & 27 & 27 & 27 & 27 & 26 \\
\hline Years per country (avge.) & 10.81 & 10.81 & 10.81 & 10.81 & \\
\hline
\end{tabular}

Notes: Dependent variable is gen. govt. primary balance (percent of GDP) in all specifications. 'TOT' denotes the terms of trade; 'min. exp.' are mineral exporting countries; 'ext. disb.' are external disbursements; $A R(x)$ indicates an autoregressive process of order ' $x$ '; 'System GMM' denotes the Blundell-Bond System GMM Estimator; 'GLS' is Generalized Least Squares. Robust standard errors are reported in parentheses, except for specification (5) where a range of coefficient estimates is shown. Symbols ${ }^{* *},{ }^{* *}$ and * denote statistical significance at 1 percent, 5 percent and 10 percent levels respectively. 


\section{References}

Abiad, A. and Ostry, J. 2005. Primary Surpluses and Sustainable Debt Levels in Emerging Market Economies, IMF Policy Discussion Paper 05/6, International Monetary Fund, Washington, DC.

Adedeji, P., C. Ahokpossi, C. Battiati, and Farid, M. 2016. "A Probabilistic Approach to Fiscal Space and Prudent Debt Level: Application to Low-Income Developing Countries." IMF Working Paper 16/163, International Monetary Fund, Washington, DC.

Adedeji, P., and O. Williams. 2007. "Fiscal Reaction Functions in the CFA Zone: An Analytical Perspective.” IMF Working Paper 07/232, International Monetary Fund, Washington, DC.

Aizienman, J. and Jinjarak, Y. 2010. “De facto Fiscal Space and Fiscal Stimulus: Definition and Assessment." NBER Working Paper 16539, National Bureau of Economic Research, Cambridge, MA.

Berg, A., Portillo, R., Yang, C.S. and Zanna, L-F. 2013. "Public Investment in Resource Abundant Low-Income Countries.” IMF Economic Review, 61(1), 92-129.

Blundell, R., and Bond, S. 1998. "Initial Conditions and Moment Restrictions in Dynamic Panel Data Models." Journal of Econometrics, 87, 115-143

Bohn, H. 1998. "The Behavior of US Public Debt and Deficits." The Quarterly Journal of Economics, 113(3) 949-963.

Botev, J., J. Fournier and A. Mourougane. 2016. "A Reassessment of Fiscal Space in OECD Countries.” OECD Economics Department Working Papers, No. 1352, OECD Publishing, Paris. http://dx.doi.org/10.1787/fec60e1b-en

Bova, E., Ruiz-Arranz, M., Toscani, F. and Ture, H.E. 2016. "The Fiscal Costs of Contingent Liabilities: A New Dataset.” IMF Working paper 16/14, International Monetary Fund, Washington, DC.

Briguglio L., Cordina, G., Farrugia, M. and Vella, S. 2008. "Economic Vulnerability and Resilience-Concepts and Measurements." UNU-WIDER Research Paper 2008/55, United Nations University.

Brun, J-F., Chambas, G., Combes, J-L., Dulbecco, P., Gastambide, A., Guérineau, S., Guillaumont, S. and Rota Graziosi, G. 2006. "Fiscal Space in Developing Countries." CERDI, France. 
Budina, N., Kinda, T., Schaechter, A., and Weber, A. 2012. "Fiscal Rules at a Glance: Country Details from a New Dataset.” IMF Working Paper 12-273, International Monetary Fund, Washington, DC.

Buffie, E.F., Berg, A., Pattillo, C., Portillo, R. and Zanna, L-F. 2012. "Public Investment, Growth, and Debt Sustainability: Putting Together the Pieces." IMF Working Paper 12/144, International Monetary Fund, Washington, DC.

Celasun, O., Debrun, X. and Ostry, J. 2007. "Primary Surplus Behavior and Risks to Fiscal Sustainability in Emerging Market Countries: A "Fan-Chart" Approach." IMF Staff Papers, 53(3), 401.

Debrun, X., Jarmuzek, M., and Shabunina, A. 2017. "Public Debt: Not Safe at Any Speed." IMF Working Paper, forthcoming.

Deléchat, C., Yang, S., Clark, W., Gupta, P., Kabedi-Mbuyi, M., Koulet-Vickot, M., Macario, C., Orav, T., Rosales, M., Tapsoba, R. and Zhdankin, D. 2017. "Harnessing Resources Wealth for Inclusive Growth in Fragile Western African States.” Journal of African Economies, 1-38.

Ghosh, A. Kim, K. Mendoza, E., Ostry, J. and Qureshi, M. 2013. "Fiscal Fatigue, Fiscal Space and Debt Sustainability in Advanced Economies." Economic Journal, 123, F4F30.

Gupta, S., A. Kangur, C. Papageorgiou, and Abdoul W. 2014. "Efficiency-Adjusted Public Capital and Growth." World Development, Vol. 57, pp. 164-178.

Heller, P.S. 2005. “Understanding Fiscal Space.” IMF Policy Discussion Paper, 05/4, International Monetary Fund, Washington, DC.

Heller, P.S., Katz, M., Debrun, X., Thomas, T., Koranchelian, T., and Adenauer, I. 2006. "Making Fiscal Space Happen! Managing Fiscal Policy in a World of Scaled-up Aid." World Economics, 7 (3), 89-131.

Horton, M. and El-Ganainy, A. 2012. "Fiscal Policy: Taking and Giving Away." Finance and Development, March.

International Monetary Fund. 2009. "Fiscal Rules Anchoring Expectations for Sustainable Public Finances.” Policy Paper, IMF, Washington.

— 2011. "The Public Sector Debt Statistics Guide: Guide for Compilers and Users." Inter-Agency Task Force on Finance Statistics, IMF, Washington.

_. 2012. "Macroeconomic Policy Frameworks for Resource-rich Developing Countries.” Policy Paper, IMF, Washington. 
_ 2013a. "Strengthening Fiscal Policy Space." Regional Economic Outlook, African Department, May 2013, Sub-Saharan Africa Building Momentum in a Multi-Speed World, chapter 2: May, 23-37.

- 2013b. Nigeria: Publication of Financial Sector Assessment Program Documentation-Detailed Assessment of Compliance of the Basel Core Principles for Effective Banking Supervision, IMF Country Report No. 13/146.

—. 2014. "Macroeconomic Developments in Low-Income Developing Countries." Policy Paper, IMF, Washington.

— 2015a. "Financing for Development—Revisiting the Monterrey Consensus." Policy Paper, IMF, Washington.

—. 2015b. "Financing for Development: Enhancing the Financial Safety Net for Developing Countries.” Policy Paper, IMF, Washington.

_ 2015c. "Public Debt Vulnerabilities in Low-income Developing Countries: The Evolving Landscape.” Policy Paper, IMF, Washington.

- 2015d. The Commodities Roller Coaster: A Fiscal Framework for Uncertain Times, October 2015 Fiscal Monitor, IMF, Washington.

_ 2016a. "Financing for Development: Enhancing the Financial Safety Net for Developing Countries-Further Considerations." Policy Paper, IMF, Washington.

— . 2016b. "Assessing Fiscal Space: An Initial Consistent Set of Considerations." Policy Paper, IMF, Washington.

—. 2016c. "Heavily Indebted Poor Countries (HIPC) Initiative and Multilateral Debt Relief Initiative (MDRI) - Statistical Update.” Policy Paper, IMF, Washington.

_. 2016d. "Regional Economic Outlook: Sub-Saharan Africa." IMF, Washington, October.

_. 2016e. "Macroeconomic Developments and Prospects in LIDCs." Policy Paper, IMF, Washington.

_ . 2016f. "Managing Fiscal Risks: Best Practice and Analytical Tools." Policy Paper, IMF, Washington.

International Monetary Fund and World Bank. 2012. "Revisiting the Debt Sustainability Framework for Low-Income Countries.” January. 
Geiregat, C., Kaffo Melou, M. and Sumlinski, M. 2014. “A 'Fan-Chart Approach' to Debt Sustainability in Post-HIPC Low-Income Countries." IMF Working Paper 14/102, International Monetary Fund, Washington, DC.

Laeven, L. and Valencia, F. 2012. "Systemic Banking Crises Database: An Update.” IMF Working Paper 12/163, International Monetary Fund, Washington, DC.

MEFMI. 2013. Joint MEFMI-OECD Study on Contingent Liabilities in Malawi, Macroeconomic and Financial Management Institute of Eastern and Southern Africa.

Mendoza, E. and Ostry, J. 2008. "International Evidence on Fiscal Solvency: Is Fiscal Policy Responsible?” Journal of Monetary Economics, 55, 1081-1093.

Ostry, J.D., A.R. Ghosh, J.I. Kim, and M. Qureshi. 2010. "Fiscal Space.” Staff Position Note 2010/11.

Polockova, H. 1999. “Contingent Government Liabilities: A Hidden Fiscal Risk.” Finance and Development, 36 (1).

Roy, R. and Heuty, A. 2009. "Policy Options for Financing Human Development.” United Nations Development Programme.

Roy, R., Heuty, A. and Letouzé, E. 2007. "Fiscal Space for What? Analytical Issues from a Human Development Perspective." UNDP's paper for G-20 workshop on fiscal policy-Istanbul, June 30-July 2.

Schick, A. 2009. "Budgeting for Fiscal Space.” OECD Journal on Budgeting, Vol. 9/2.

Schmidt-Traub, G. 2015. "Investment Needs to Achieve the Sustainable Development Goals. Understanding the Billions and Trillions." SDSN Working Paper, United Nations, New York.

Shen, W., Yang, S., and L.F. Zanna. 2015. "Government Spending Effects in Low-Income Countries." IMF Working Paper 15/286, International Monetary Fund, Washington, DC.

United Nations Development Report (UNDP). 2011. "Towards Human Resilience: Sustaining MDG Progress in an Age of Economic Uncertainty.” September.

United Nations. 2015. "Transforming our World: The 2030 Agenda for Sustainable Development" https://sustainabledevelopment.un.org/post2015/transformingourworld/publication

Van der Ploeg, F. and Venables, A-J. 2011. "Harnessing Windfall Revenues: Optimal Policies for Resource-Rich Developing Economies." The Economic Journal, 121, 130. 
Weber, A. 2012. "Stock-Flow Adjustments and Fiscal Transparency: A Cross-Country Comparison.” IMF Working Paper 12/39, International Monetary Fund, Washington, DC.

World Bank. 2009. "The Global Economic Crisis: Assessing Vulnerability with a Poverty Lens." World Bank, Washington, DC.

. 2013. Republic of Burundi, Public Expenditure Review: Strengthening Fiscal Resilience to Promote Government Effectiveness, World Bank, Washington, DC.

_. 2015. "Global Economic Prospects: Having Fiscal Space and Using It.” World Bank Report, Washington, DC. 